\title{
The Tolbachik volcanic massif: A review of the petrology, volcanology and eruption history prior to the 2012-2013 eruption
}

\author{
T.G. Churikova ${ }^{\text {a,* }}$, B.N. Gordeychik ${ }^{\text {b }}$, B.R. Edwards ${ }^{c}$, V.V. Ponomareva ${ }^{a}$, E.A. Zelenin ${ }^{d}$ \\ a Institute of Volcanology and Seismology, Far East Branch Russian Academy of Sciences, 9 Piip Boulevard, Petropavlovsk-Kamchatsky 683006, Russia \\ b Institute of Experimental Mineralogy, Russian Academy of Sciences, Academica Osypyana ul., 4, Chernogolovka, Moscow region 142432, Russia \\ c Department of Earth Sciences, Dickinson College, Carlisle, PA 17013, USA \\ d Geological Institute, Russian Academy of Sciences, Pyzhevsky lane 7, Moscow 119017, Russia
}

\section{A R T I C L E I N F O}

\section{Article history:}

Received 14 February 2015

Accepted 10 October 2015

Available online 23 October 2015

\section{Keywords:}

Tolbachik volcanic massif

Klyuchevskaya group

Subduction

Eruption history

Chemical evolution

Volcano monitoring

\begin{abstract}
A B S T R A C T
The primary goal of this paper is to summarize all of the published data on the Tolbachik volcanic massif in order to provide a clear framework for the geochronologic, petrologic, geochemical and to a lesser extent the geophysical and tectonic characteristics of the Tolbachik system established prior to the 2012-2013 eruption. The Tolbachik massif forms the southwestern part of the voluminous Klyuchevskoy volcanic group in Kamchatka. The massif includes two large stratovolcanoes, Ostry ("Sharp") Tolbachik and Plosky ("Flat") Tolbachik, and a $70 \mathrm{~km}$ long zone of the basaltic monogenetic cones that form an arcuate rift-like structure running across the Plosky Tolbachik summit. The Tolbachik massif gained international attention after the 1975-1976 Great Tolbachik Fissure Eruption (GTFE), which was one of the largest eruptions of the 20th century and one of the six largest basaltic fissure eruptions in historical time. By the end of the GTFE, $2.2 \mathrm{~km}^{3}$ of volcanic products of variable basaltic compositions with MORB-like isotopic characteristics covered an area of $>1000 \mathrm{~km}^{2}$. During the following three decades more than 700 papers on various aspects of this eruption have been published both in national and international journals. Although the recent 2012-2013 eruption, which is the main topic of this volume, was not as long as the GTFE in duration or as large in area and volume of the erupted deposits, it brought to the surface a unique volcanic material never found before. In order to understand the data from new eruptions and make significant progress towards a better understanding of the Tolbachik magmatic system it is important to be able to put the new results into the historic context of previous research.
\end{abstract}

(c) 2015 Elsevier B.V. All rights reserved.

\section{Introduction}

The Tolbachik volcanic massif, which comprises two stratovolcanoes, Ostry Tolbachik and Plosky Tolbachik, as well as numerous scoria cones and related lava flows, is one of the largest and most active volcanic areas in Kamchatka (Fig. 1). This Late Pleistocene-Holocene massif erupted repeatedly during Holocene and historical times (less than 300 years for Kamchatka). The first historical account of activity at Tolbachik was written by Russian explorer Stepan Krasheninnikov (Krasheninnikov, 1755), who described the Tolbachik eruption of 1739. Subsequently, during the 20th century several researchers studied and published data from numerous eruptions from the Plosky Tolbachik summit as well as at the surrounding monogenetic volcanic fields on the massifs' southwestern and northeastern flanks (Fig. 2, e-Table 1). Most of these publications described eruption dynamics and the post-eruption morphologies at the volcano summit and lava flows (i.e. Vlodavets, 1937; Piip, 1946, 1954; Popkov, 1946; Menyailov, 1953; Sirin and Farberov, 1963; Kirsanov and Ponomarev, 1974).

\footnotetext{
* Corresponding author.

E-mail address: tchurikova@mail.ru (T.G. Churikova).
}

However, Tolbachik became recognized as a volcano of global significance after the Great Tolbachik Fissure Eruption (1975-1976; GTFE), when four new monogenetic cones and associated lava flows formed during on eruption on the southern slope of Plosky Tolbachik volcano that lasted for 1.5 years (Fedotov, 1984). The eruption produced both high-Mg and high-Al basalts and had a total volcanic product (lava and scoria) volume of $2.2 \mathrm{~km}^{3}$, making it one of the largest eruptions of the 20th century. In the time between the 1975-1976 GTFE and the 2012-2013 eruption, two books and numerous peer-reviewed papers in the Russian and international literature (Fig. 2) provide data mainly on the 1975-1976 Tolbachik eruption (e.g., Fedotov and Markhinin, 1983; Fedotov, 1984; Fedotov and Masurenkov, 1991; Kersting, 1995; Hochstaedter et al., 1996; Kepezhinskas et al., 1997; Turner et al., 1998; Pineau et al., 1999; Volynets et al., 2000; Churikova et al., 2001; Münker et al., 2004; Portnyagin et al., 2007a). Thus at present most of the existing information on the Tolbachik volcanic massif has been focused on the 1975-1976 eruption. Over the same time period the other parts of this large massif and its adjacent monogenetic cones and lava flows have been studied in much less detail.

In 2012-2013 a new, large eruption from monogenetic cones occurred on the same fissure system that produced the 1975-1976 


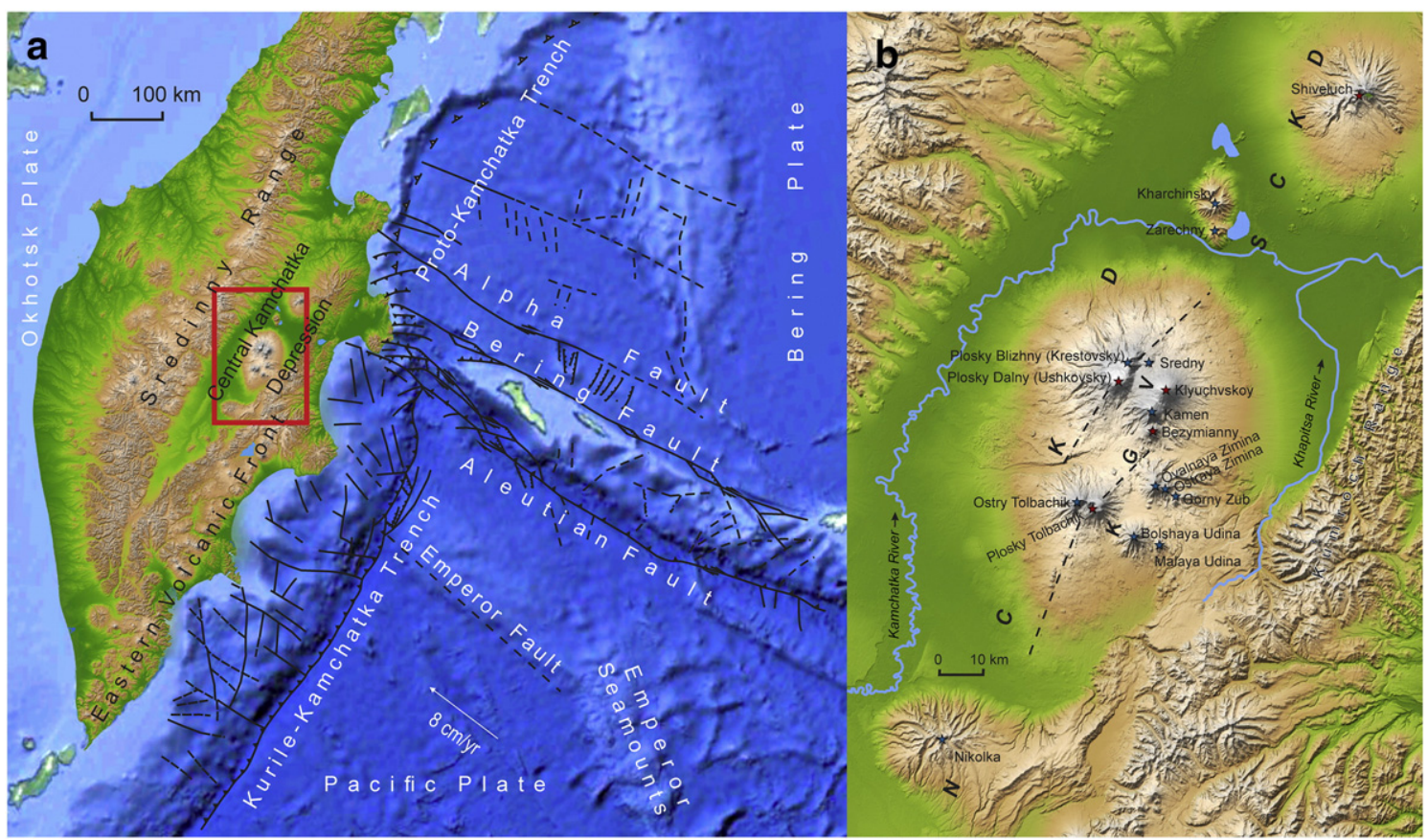

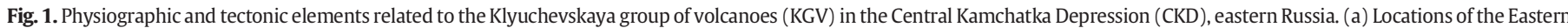

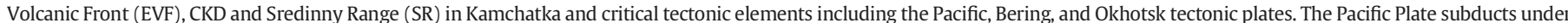

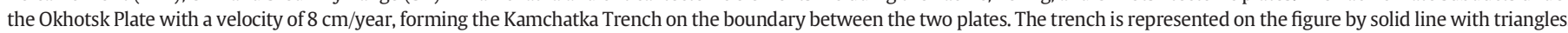

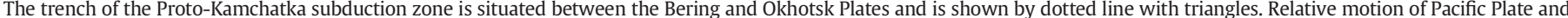

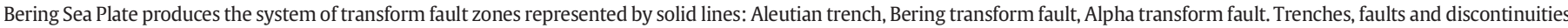

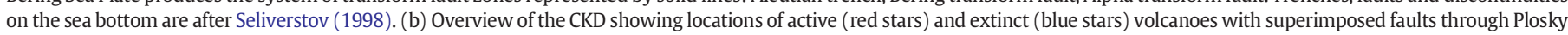
Tolbachik volcano and Ploskye Sopki (Plosky Blizhny and Plosky Dalny) massif drawn by dashed lines from (Melekestsev et al., 1991).

eruption, on the southern slope of Plosky Tolbachik volcano. The new eruption is the focus of this special issue of JVGR. The purpose of this work is to give an overview of the state of knowledge of the geology, tectonics, petrology, geochemistry, geophysics and history of the Tolbachik volcanic massif up to the point just prior to the initiation of the 2012-2013 eruption.

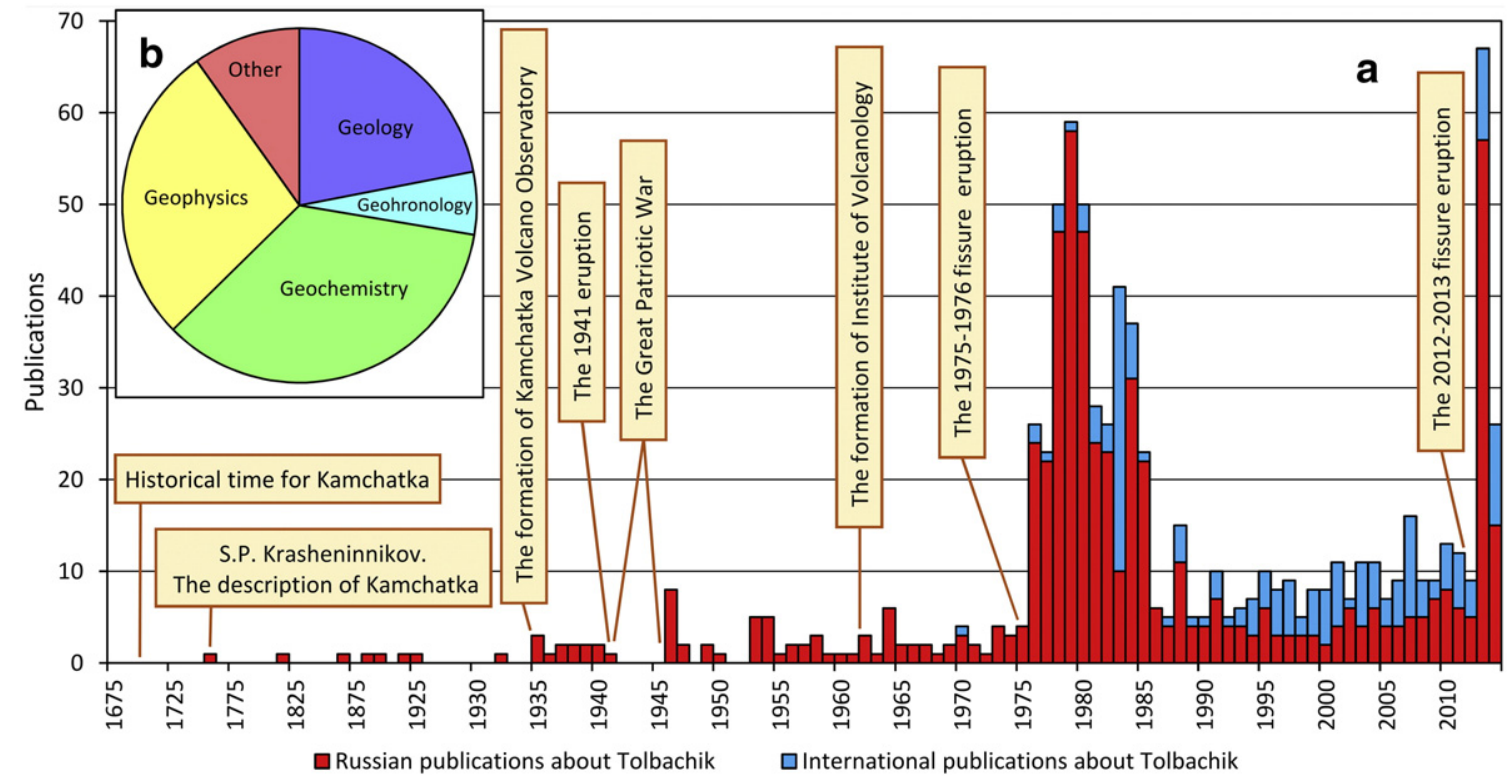

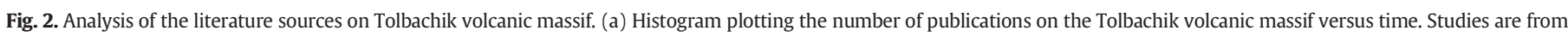

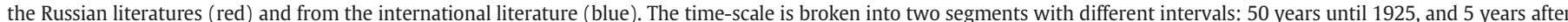

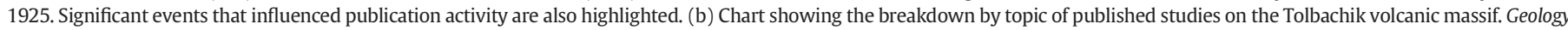

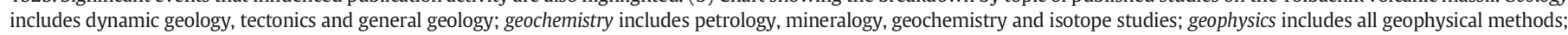
geochronology includes tephrochronology and geomorphology; others include all other topics. 


\section{Overview of the physiographic and tectonic setting of the Klyuchevskaya group of volcanoes}

\subsection{Geology and tectonics of the Central Kamchatka Depression and the Klyuchevskaya group of volcanoes}

The Kamchatka arc is located at the northeastern convergent boundary of the Okhotsk and Pacific plates (Fig. 1a). The Pacific Plate is presently subducting at a rate of 8-9 cm/yr (DeMets et al., 1990; Geist and Scholl, 1994; Scholl, 2007). The slab below Kamchatka dips at $55^{\circ}$ but shallows to $35^{\circ}$ in the north where the Emperor Seamount chain, which formed on top of the Pacific Plate, is being subducted (Gorbatov et al., 1997). According to seismic data the depth of the Wadati-Benioff zone increases across the Kamchatka from $60-100 \mathrm{~km}$ below the arc front to more than $300 \mathrm{~km}$ below the southern part of back arc (Gorbatov et al., 1997).

Quaternary arc volcanism in Kamchatka comprises three zones parallel to the Kurile-Kamchatka trench that consistently shift relative each other slightly to the north from east to west (Fig. 1a): the Eastern Volcanic Front (EVF), the graben-like Central Kamchatka Depression (CKD) with the active Klyuchevskaya group of volcanoes (KGV) at its northern end, and the Sredinny Range (SR) in back arc. During historical time in Kamchatka active volcanism has mainly been observed in the EVF and KGV. However, Late-Pleistocene and Holocene volcanism is present in all three volcanic zones in comparably large volumes (Ponomareva et al., 2007a).

The present tectonic configuration of Kamchatka was established in the Late Miocene-Pliocene ( 6 to $3 \mathrm{Ma})$. It formed after the serial accretion from south to north of the Kronotsky terrain to the Kamchatka Peninsula (Seliverstov, 1998; Alexeiev et al., 2006; Lander and Shapiro, 2007) and the $200 \mathrm{~km}$ migration of the volcanic front from the SR eastwards to its present position. As a result the SR switched from the volcanic front to a back arc position with a corresponding change in trace element signatures from strongly depleted plateau lavas to enriched basalts that erupted from isolated scoria cones and stratovolcanoes (Volynets et al., 2010).

The northern edge of the subducted plate under Kamchatka is not well defined. It is marked by the termination of Holocene volcanism at Shiveluch volcano (Volynets et al., 1997; Yogodzinski et al., 2001), and at the Shisheisky complex of monogenetic cones (Portnyagin et al, 2007a; Bryant et al., 2011). The SR back arc extends up to the Tobeltsen cone (Pevzner, 2006). According to Volynets et al. (2010), the northern edge of the subducted plate is spread across a $150 \mathrm{~km}$ wide transitional zone extending from the Aleutian through the Bering to the Alfa transform faults.

The CKD is situated near a triple junction where the Pacific, Bering and Okhotsk plates come together and form two active boundaries: the convergent Kurile-Kamchatka trench and Aleutian-Bering-Alfa transform faults (Seliverstov, 1998; Fig. 1a). Different processes have been proposed to explain the origins and characteristics of magmatism in this area: opening of a slab window (Yogodzinski et al., 2001), detachment of fragments from the Pacific Plate (Levin et al., 2002), slab edge heating in the mantle wedge due to decreasing thickness of the Pacific Plate below the Emperor Seamounts (Davaille and Lees, 2004), or a large input from slab melting (Portnyagin et al, 2007a).

Geophysical studies (Balesta, 1991) have shown that crustal thickness along the Kamchatka Peninsula varies from $20 \mathrm{~km}$ to $42 \mathrm{~km}$, increasing from the south to the north. Recent tomography and other geophysical studies confirm these data including: (1) average crustal thickness in excess of $30 \mathrm{~km}$, and (2) the gradational nature of the crust-mantle transition below Kamchatka (Balesta, 1991; Iwasaki et al., 2013; Koulakov et al., 2013). Deep seismic sounding shows that the maximum crustal thickness in Kamchatka exists below the KGV, reaching 40-42 km there and decreasing to $30 \mathrm{~km}$ beneath the EVF and the SR. The increase in crustal thickness below the KGV has been attributed to the extensive crust-mantle transition zone below active volcanoes (Balesta, 1991). Based on geophysical data, the main zones of magma storage are also concentrated at the base of the crust or inside/below the crust-mantle transitional zone (e.g., Levin et al., 2014). The depths to the magma storage zones vary from 25 to $50 \mathrm{~km}$. At the same time below some volcanoes (including the scoria cones of Tolbachik) crustal magma chambers have been identified at depths from 1.5-2.0 km and 10-20 km (Balesta, 1991).

The most detailed recent overviews of Kamchatka magmatism and seismicity are by Eichelberger et al. (2007) and by Iwasaki et al. (2013), respectively. The CKD volcanoes stretch from the Pleistocene, half-ruined Nikolka volcano in the south to the active Shiveluch volcano and a series of monogenetic cones in the north, with a total area of about $8500 \mathrm{~km}^{2}$ (Melekestsev et al., 1991; Fig. 1b). The northern active part of the CKD comprises 17 volcanoes. Following previous workers (Melekestsev et al., 1974; Churikova et al., 2001; Ponomareva et al., 2007a) we divide the CKD into the NCKD (to the north of Kamchatka River) and the SCKD (to the south of Kamchatka River). The SCKD includes the KGV and Nikolka volcano, and the NCKD includes Shiveluch, Kharchinsky, and Zarechny volcanoes and the surrounding monogenetic cones (Fig. 1b). The Tolbachik volcanic massif is situated in southwestern part of the KGV.

In the Late Pleistocene the KGV basement was split by series of faults into several tectonic blocks (Melekestsev et al., 1974; Ermakov, 1977). Those considered to be tectonically stable blocks are located in the central and southeastern parts of the KGV, which do not include the southwestern block underlying the Tolbachik volcanic massif. The boundary between the central and southwestern blocks follows the Studenaya River, while the other boundaries are covered by younger volcanic deposits (Melekestsev et al., 1974). Klyuchevskoy, Kamen, and Bezymianny volcanoes and the Ploskye Sopki massif are located on a large plateau of basalt-basaltic andesite composition with an elevation about $1500 \mathrm{~m}$ a.s.l. These plateau lavas outcrop within the Studenaya River valley and are centered around the Ploskye Sopki volcanic massif, which comprises Plosky Dalny (syn. Ushkovsky) and Plosky Blizhny (syn. Krestovsky) volcanoes (Sirin, 1968; Flerov and Ovsyannikov, 1991). The southwestern part of the KGV, including the Tolbachik volcanic massif, is underlain by a series of lava flows ranging in composition from basalt to andesite, which outcrop within the Khapitsa River valley, with elevations of about $1000 \mathrm{~m}$ a.s.l. (Timerbaeva, 1967).

Two large zones of monogenetic scoria cones and associated lava flow fields extend through the Tolbachik and Ploskye Sopki volcanic massifs. These zones are the youngest rift-like structures inside the KGV that are covered by volcanic material (Melekestsev et al., 1991; Fig. 1b). These two zones are surprisingly similar; both have 1) the same orientations, 2) northern and southern parts, 3) changes in their orientations from SSW-NNE to SW-NE across the summits of the volcanic massifs, 4) large volumes of erupted products; and 5) relatively young ages (Late Pleistocene-Holocene). It is likely that the monogenetic volcanism is connected to extension within the CKD. However, the absence of the direct measurements of this extension and of rocks with true intraplate geochemical characteristics means that this hypothesis requires further testing.

\subsection{Volcanoes of the KGV and their temporal evolution}

The KGV comprises four active volcanoes - Klyuchevskoy, Bezymianny, Plosky Tolbachik, and Plosky Dalny (Fedotov and Masurenkov, 1991) and nine that are considered to be extinct, including Kamen, Plosky Blizhny, Sredny, Ostry Tolbachik, Ovalnaya Zimina, Ostraya Zimina, Bolshaya Udina, Malaya Udina and Gorny Zub (Fig. 1b). Due to its unique position and almost constant activity, the KGV has been the focus of extensive research. More than 1000 papers were published on the area, including works on petrology (e.g., Flerov et al., 1984; Flerov and Ovsyannikov, 1991; Khrenov et al., 1991; Khubunaya et al., 1994; Volynets, 1994; Kersting and Arculus, 1995; 
Ozerov et al., 1997; Volynets et al., 1997, 2000; Khubunaya and Sobolev, 1998; Turner et al., 1998, 2007; Pineau et al., 1999; Dorendorf et al., 2000; Ozerov, 2000; Churikova et al., 2001, 2007, 2013; Ishikawa et al., 2001; Mironov et al., 2001; Yogodzinski et al., 2001; Dosseto et al., 2003; Bindeman et al., 2004; Münker et al., 2004; Portnyagin et al., 2007a, 2007b; 2009; Auer et al., 2009; Gorbach and Portnyagin, 2011; Mironov and Portnyagin, 2011; Almeev et al., 2013a,b; Gorbach et al., 2013; Dosseto and Turner, 2014), geophysics (e.g., Tokarev and Zobin, 1970; Balesta, 1991; Gorelchik et al., 1997, 2004; Levin et al., 2002; Park et al., 2002; Davaille and Lees, 2004; Khubunaya et al., 2007; Senyukov et al., 2009; Fedotov et al., 2010, 2011; Thelen et al., 2010; Koulakov et al., 2011; Grapenthin et al., 2013; Iwasaki et al., 2013; Kugaenko et al., 2013; West, 2013), geochronology (e.g., Braitseva et al., 1991; Calkins, 2004; Ponomareva et al., 2006, 2007a, 2013; Pevzner et al., 2014) and other related subjects (e.g., Ovsyannikov et al., 1985; Belousov, 1995, 1996; Muravyev et al., 2002; Melekestsev, 2005; Grishin and Shlyakhov, 2009; Gilichinsky et al., 2010; Gordeev and Girina, 2014). However, most of the publications concentrate on recently active volcanoes and the most recent volcanic products.

Holocene activity within the KGV is best documented by tephrochronological methods (Braitseva et al., 1993); however, these methods can be used only for eruptions after the Last Glacial Maximum (10-11 ka for Kamchatka). On the other hand, only a limited number of ${ }^{40} \mathrm{Ar} /{ }^{39} \mathrm{Ar}$ and $\mathrm{K} / \mathrm{Ar}$ isotopic age determinations indicate Middle to Late Pleistocene ages for the lower part of stratovolcano stratigraphy or their basement rocks. Most age estimates for volcanoes thought to be from the Late Pleistocene period are based on edifice morphology and on their stratigraphic relationships with glacial deposits (Melekestsev et al., 1971; Braitseva et al., 1995; Ponomareva et al., 2007a).

Large plateaus of lavas below the KGV were erupted at $274 \mathrm{ka}$ in the southeastern KGV at the Khapitsa River, and at $262 \mathrm{ka}$ in the central part of the KGV at the Studenaya River $\left({ }^{40} \mathrm{Ar} /{ }^{39} \mathrm{Ar}\right.$; Calkins, 2004). During the same time interval (188-366 ka; K/Ar, Nishizawa et al., 2014) volcanic activity at Kumroch Ridge (EVF), just to the east of the KGV, produced about 25 scoria cones and several small volcanic massifs (Uspensky and Shapiro, 1984). Based on the relationship with glacial deposits (Melekestsev et al., 1971; Braitseva et al., 1995) it was suggested that most of the KGV and NCKD stratovolcanoes started to form before 40-50 ka with an oldest Middle Pleistocene age for Gorny Zub volcano. This is confirmed by recent ${ }^{40} \mathrm{Ar} /{ }^{39} \mathrm{Ar}$ dating of an early lava flow of Shiveluch volcano, which is about 82 ka (Pevzner et al., 2014). The youngest KGV volcanoes, Klyuchevskoy and Bezymianny, started to grow only at $7 \mathrm{ka}$ (Braitseva et al., 1995) and $5.5 \mathrm{ka}$ (Braitseva et al., 1991), respectively and are still highly active. The zone of monogenetic cones at Ploskye Sopki apparently ceased activity at 10.2 ka (Ponomareva et al., 2013) and about this time (Braitseva et al., 1984) a second monogenetic volcanic field began to form at the Tolbachik volcanic massif, which is also presently active (Fig. 3 ).

\subsection{Petrology and geochemistry of the CKD}

The geochemical diversity of volcanic rocks within the CKD in comparison to their parent magmas remains one of the most intriguing issues of magma generation in this area (see also overview paper by Portnyagin et al., 2007a). Most rocks of the SCKD and NCKD belong to the medium-K calc-alkaline series, samples of which can be found at each CKD volcano. Additionally, high-K basalts, trachybasalts and trachyandesites are found at some volcanoes, including the Ploskye Sopki volcanic massif, the Tolbachik volcanic massif, and a few samples from the poorly studied Nikolka volcano (Flerov et al., 1984; Churikova et al., 2001). These rocks are highly enriched in alkalies, phosphorous and incompatible elements compared to other CKD lavas (Figs. 4, 5) and form a tholeiitic trend on a Miyashiro diagram (Fig. 4b). Tolbachik samples are presented in both trends. The presence of two trends suggests different parental melts and different evolutionary paths for magma production and evolution within the CKD. The rocks inside each trend are also highly variable in composition, and each KGV volcano has its own petrological/geochemical signature (e.g., Dosseto et al., 2003; Turner et al., 2007; Churikova et al., 2013). The main task of future geochemical research in this area is to understand what processes and/or source region conditions are responsible for this diversity.

Until the decade of 1970-80, research on CKD/KGV volcanism did not consider subduction as the magma generating process (e.g., Fedotov and Markhinin, 1983; Fedotov, 1984). But within the period 1990-2005 several subduction-related processes were suggested to explain the

\begin{tabular}{|c|c|c|c|c|}
\hline \multirow{2}{*}{ Klyuchevskoy } & Monogenetic cones & & & \\
\hline & Stratovolcano & & & \\
\hline \multirow{2}{*}{ Bezymianny } & Lava flow unit & & & \\
\hline & Pre-Bezymianny & & & \\
\hline \multirow{2}{*}{ Ploskye Sopky } & Monogenetic cones & & & \\
\hline & Stratovolcano & & & \\
\hline Shiveluch & Stratovolcano & 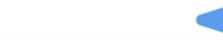 & 0 & \\
\hline \multirow{3}{*}{ Kamen } & Monogenetic cones & & & \\
\hline & Lava flow and dike units & & $<$ & \\
\hline & Pyroclastic unit & & $\longrightarrow$ & \\
\hline \multirow{3}{*}{ Tolbachik } & Monogenetic cones & & & \\
\hline & Stratovolcano & & 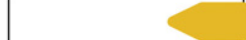 & \\
\hline & Pedestal & 0 & 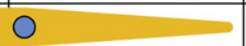 & \\
\hline Gorny Zub & Stratovolcano & $\longrightarrow$ & & \\
\hline \multirow{2}{*}{ KGV Basement } & Studenaya plateau & W & 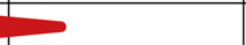 & \\
\hline & Hapitsa plateau & 0 & 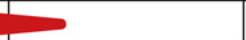 & \\
\hline
\end{tabular}

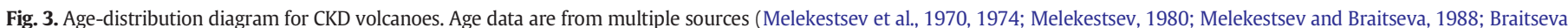

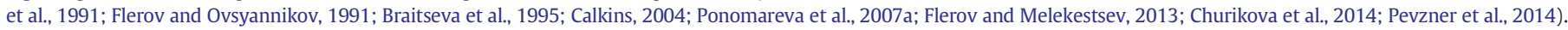

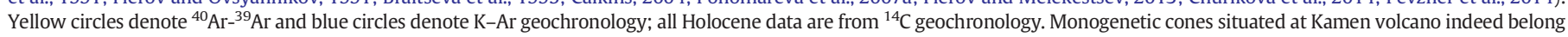
to Klyuchevskoy volcano (Churikova et al., 2013). 

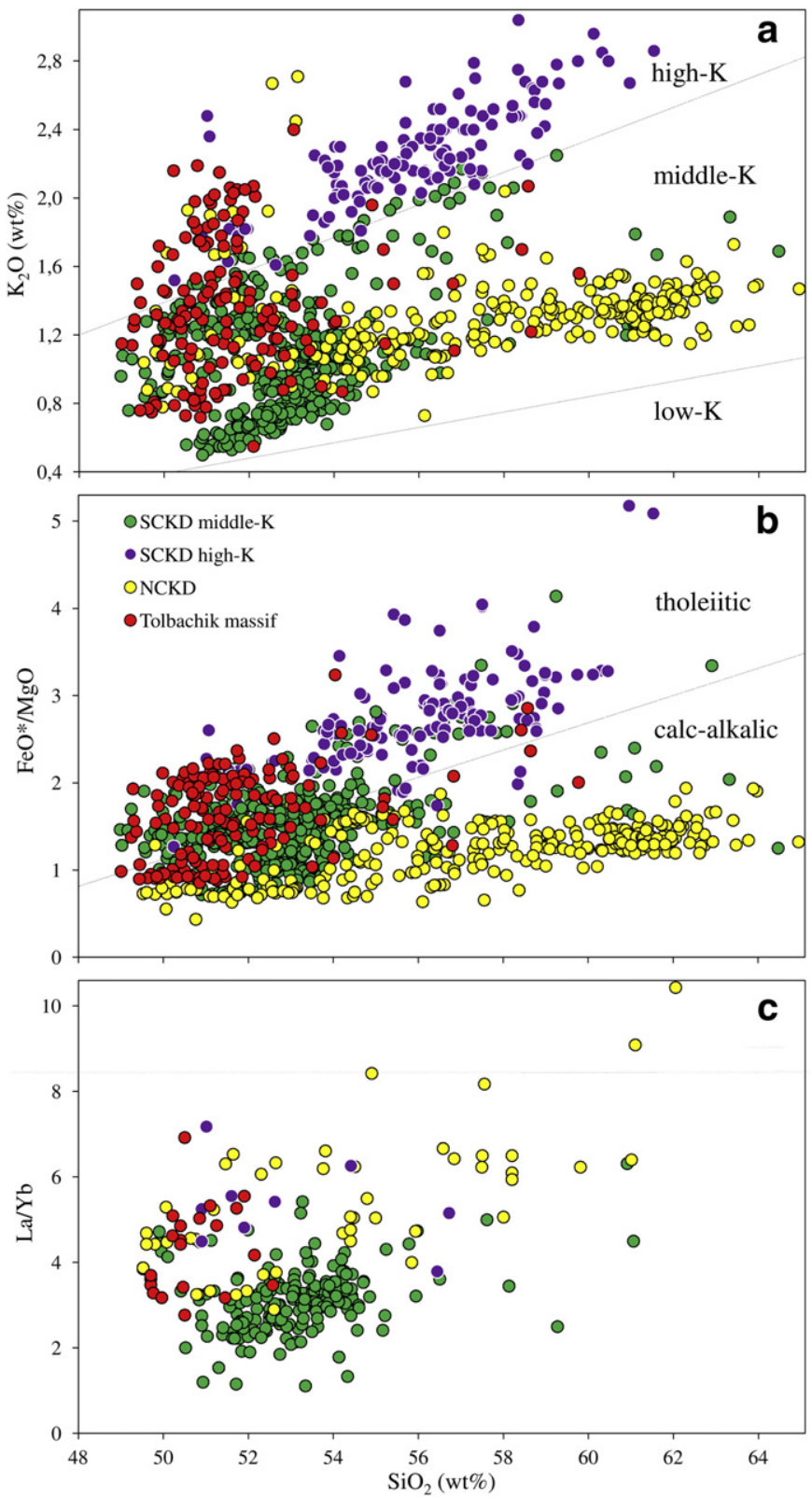

Fig. 4. Classification diagrams and $\mathrm{La} / \mathrm{Y}$ vs. $\mathrm{SiO}_{2}$ for the $\mathrm{CKD}$ rocks. (a) $\mathrm{K}_{2} \mathrm{O}$ vs. $\mathrm{SiO}_{2}$ with classification lines after Le Maitre (1989), showing fields of low-, medium-, and high-K arc lavas. (b) $\mathrm{FeO} / \mathrm{MgO}$ vs. $\mathrm{SiO}_{2}$ showing the classification line for tholeiitic and calc-alkalic volcanic series after Miyashiro (1974). (c) La/Yb vs. $\mathrm{SiO}_{2}$ Data are color-coded to show differences in geographic locations and differences in rock series: yellow circles (NCKD volcanoes), violet and green circles (basalt-basaltic-andesite series of the CKD divided into high-K and middle-K lavas, respectively), blue circles (rocks of the basaltic-andesite-dacite series of the CKD), and red circles (all Tolbachik volcanic massif lavas). FeO refers to total Fe in the sample expressed as FeO. Data sources are from dataset of Portnyagin et al. (2007a) with additions from several other sources (Erlich, 1966; Ermakov and Vazheevskaya, 1973; Ermakov, 1977; Churikova, 1993; Ivanov, 2008; Auer et al., 2009; Bryant et al., 2011; Almeev et al., 2013a; Churikova et al., 2013; Flerov and Melekestsev, 2013; Gorbach and Portnyagin, 2011; Gorbach et al., 2013; Ponomareva et al., 2013; Turner et al., 2013; Kayzar et al., 2014).

variations in rock geochemistry within the CKD: melting from distinct sources in the mantle wedge (Kersting and Arculus, 1994), variable mantle wedge depletion (Churikova et al., 2001), differing degrees of melting and mixing of melts from a common mantle source (Turner et al., 2007), variable fluid composition and heterogeneity in the fluid-modified mantle (Churikova et al., 2001, 2007), addition of an adakite component to the mantle sources of the KGV volcanoes (Kepezhinskas et al., 1997; Yogodzinski et al., 2001; Dosseto et al., 2003), fractionation of melts of

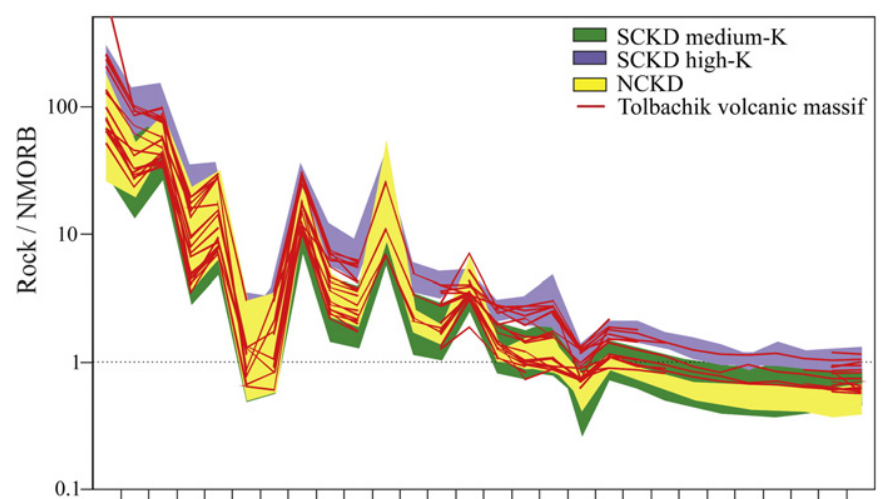

Cs Rb BaTh U Nb Ta K La Ce Pb Pr Nd Sr SmHf Zr Ti Eu GdTb DyHo Y ErTmYbLu

Fig. 5. N-MORB-normalized trace element patterns for different rock series of the CKD. The order of incompatible elements is derived from Hofmann (1988) with Cs and all REE added. NMORB values are from Sun and McDonough (1989). The colors of the fields correspond to colors of the symbols in Fig. 4. The trace element data for the Tolbachik volcanic massif are shown by red lines. Data are from Portnyagin et al. (2007a) with additional data from several other sources (Churikova, 1993; Auer et al., 2009; Bryant et al., 2011; Almeev et al., 2013a; Churikova et al., 2013; Turner et al., 2013; Kayzar et al., 2014).

different compositions at high pressure from a common arc basalt parent (Ariskin, 1999). All these processes coupled with active mantle upwelling in this region produce a strong fluid flux and elevated volcanic activity. Subduction of the Emperor Seamounts beneath the KGV has also been suggested as a potential source of the large and variable fluid flux below the KGV region (Kepezhinskas et al., 1997; Pineau et al., 1999; Dorendorf et al., 2000; Ishikawa et al., 2001).

The results from new experimental techniques and new geodynamic models during the last decade (e.g., Kessel et al., 2005; Plank et al., 2009; van Keken et al., 2011; Ruscitto et al., 2012) have shown that subduction zones appear to be hotter than previously thought and that generation of supercritical liquids and low degree slab partial melts is possible at depths of $120-180 \mathrm{~km}$. This is consistent with the lesser role for slab dehydration and aqueous fluids in the origin of island-arc magmatism and an increased significance for slab melting than previously thought. Geochemical modeling has confirmed the addition of slab melt below all the CKD volcanoes including the Tolbachik volcanic massif (Portnyagin et al., 2007a,b; Portnyagin and Manea, 2008).

On most major element, trace element and trace element ratio diagrams the NCKD and the SCKD rocks do not overlap significantly (e.g., Fig. 4b, c). An along-arc analysis of the CKD lavas shows systematic south-north enrichment in $\mathrm{SiO}_{2}$ and $\mathrm{Na}_{2} \mathrm{O}$ and depletion in $\mathrm{TiO}_{2}, \mathrm{FeO}$ and $\mathrm{CaO}$. Previous workers have explained these differences by the addition of slab melt in the NCKD mantle sources near the slab edge (Kepezhinskas et al., 1997; Volynets et al., 1997; Yogodzinski et al., 2001; Münker et al., 2004; Bryant et al., 2011). Recent research shows that these variations can be explained by a decrease in mantle wedge temperature from south to north due to decreasing slab dip and thickness of the mantle wedge (Portnyagin and Manea, 2008). In this transect the Tolbachik massif is along the southern boundary with the highest mantle wedge temperature and the thickest underlying mantle wedge.

\section{Structure and morphology of the Tolbachik volcanic massif}

\subsection{Lithospheric stratigraphy}

Unfortunately continental arc crust does not outcrop inside the KGV or in most of the CKD. Knowledge of the lithospheric stratigraphy and structure beneath the KGV derives from a wide variety of geological and geochemical sources (Fig. 6). These include i) tectonic-scale studies of terrane accretion in Kamchatka (e.g., Konstantinovskaia, 2000, 2001), ii) characterization of sparse quartzofeldspathic and peridotite 


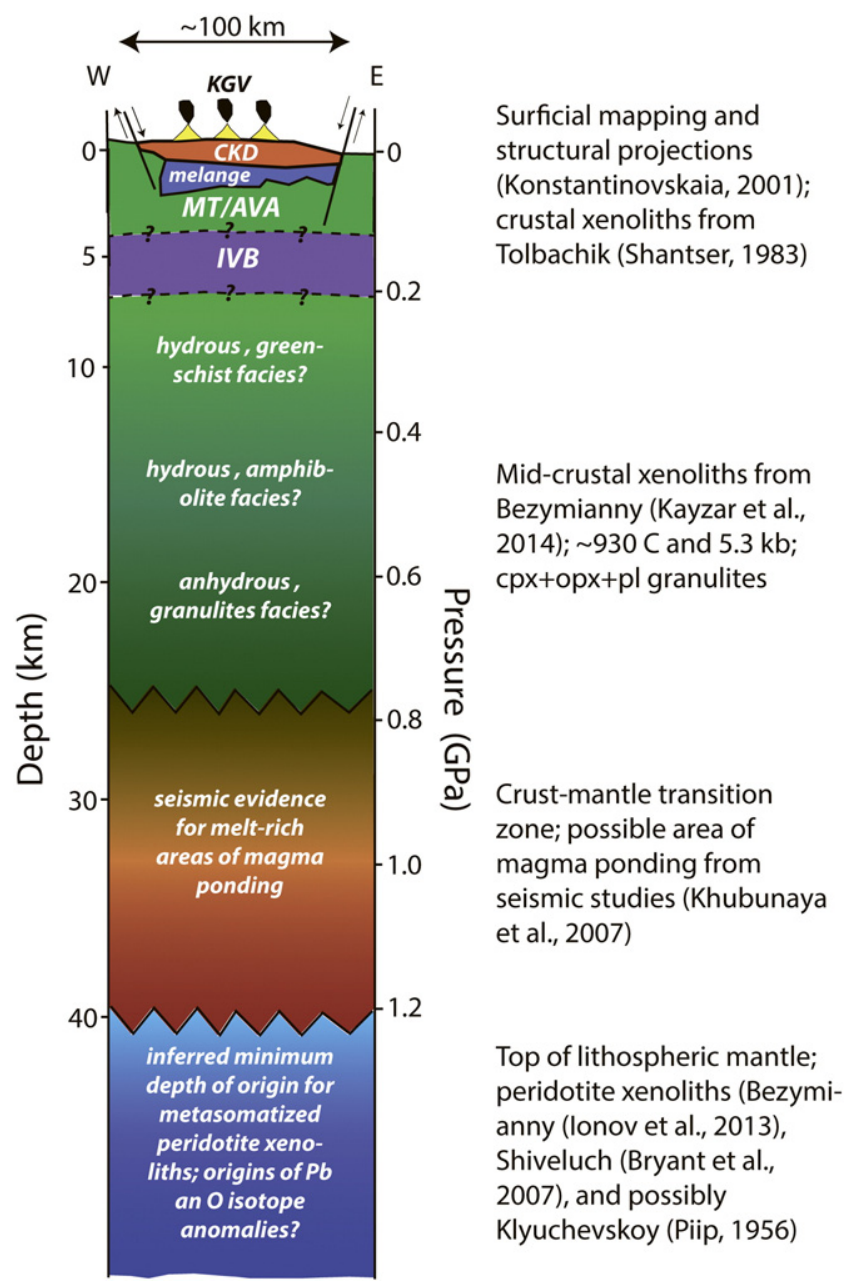

Fig. 6. Schematic compilation of information characterizing the lithosphere in the region of the KGV. Upper crustal units are after Konstantinovskaia (2001), including the relative positions of several tectonostratigraphic units (AVA and MT are the AchaivayamValaginskaya and Malkin accreted arc terranes and IVB is the Iruney-Vatuna basalts, remnant of oceanic lithosphere; all three are thought to have been emplaced by thrust faulting onto older Kamchatka basement). Information from crustal xenoliths is based on brief descriptions by Shantser (1983; Tolbachik) and Kayzar et al. (2014; Bezymianny), and data from mantle xenoliths is from Bryant et al. (2007; Shiveluch), Shcherbakov and Plechov (2010; Bezymianny), and Ionov et al. (2013; Bezymianny). Several geophysical studies have placed lower crustal magma storage areas in the 25-40 km depth range (e.g., Slavina et al., 2012). Characterization of the lithospheric mantle is also based on selected geochemical studies of lavas and their phenocrysts (Dorendorf et al., 2000; Bindeman et al., 2004).

xenoliths from deposits at Klyuchevskoy (Piip, 1956; Koloskov, 1999), Bezymianny (Shcherbakov and Plechov, 2010; Ionov et al., 2013; Kayzar et al., 2014), Shiveluch (Bryant et al., 2007) and Tolbachik (Shantser, 1983), iii) geophysical studies (e.g., Slavina et al., 2012), and iv) geochemical studies of lavas and their phenocrysts (e.g., Dorendorf et al., 2000; Bindeman et al., 2004). Surface exposures show that the Tolbachik volcanic massif is built upon an older sequence of mafic to intermediate lava flows that are part of the CKD. The upper crust underlying the CKD volcanic stratigraphy comprises a complex assortment of accreted materials that formed as oceanic islands (AchaivayamValaginskaya and Malkin terranes) and as tectonized oceanic basement (Iruney-Vatuna) and mélange (Konstantinovskaia, 2000, 2001). Crustal xenoliths erupted as bombs during the first phase of the 1975-1976 GTFE (cones I and II of the Northern Breakthrough) were identified largely as belonging to marine (based on presence of marine mollusk shells) and non-marine sedimentary sequences deposited before the formation of the CKD, as well as volcanic fragments possibly related to the CKD (Shantser, 1983). At present no samples attributable to the mid-crust have been identified. However, two samples of what are likely lower crustal samples have been identified within xenoliths suites from KGV volcanoes, and those two samples were collected at Bezymianny (Kayzar et al., 2014). Both these samples have mineralogy consistent with granulite facies conditions ( $\mathrm{Opx}+\mathrm{Cpx}+\mathrm{Pl}$ ), and two-pyroxene thermometry also gives temperatures consistent with granulite facies $\left(\sim 930{ }^{\circ} \mathrm{C}\right)$. Seismological studies suggest that the petrological Moho beneath the KGV occurs over a relatively broad depth interval (25$40 \mathrm{~km}$ ), and may be one of the locations where mantle-derived melts are stored for longer periods and undergo some fractionation processes (Levin et al., 2014). Rare peridotite xenoliths from Bezymianny (Ionov et al., 2013) and Shiveluch (Melekestsev et al., 1991; Bryant et al., 2007) have been interpreted as originating in the upper part of the metasomatized mantle. Two samples from Bezymianny are Opx-poor harzburgites cut by late stage veins of $\mathrm{Cpx}$, amphibole, spinel and feldspar; trace elements in Opx grains appear to record reactions with metasomatic fluids (Ionov et al., 2013). Samples from Shiveluch are much more diverse and include a range of peridotites (lherzolite and harzburgite) and pyroxenites, including some cut by veins of amphibole and phlogopite (Bryant et al., 2007). Dunite xenoliths from Shiveluch are interpreted as having experienced reaction with basaltic melts during transport through the mantle, while pyroxenites are thought to be cumulates (Bryant et al, 2007). Both peridotite xenolith suites appear to record high $\mathrm{fO}_{2}$ conditions ( $\triangle \mathrm{FMQ}+1$ to $+3 \log$ units; Bryant et al., 2007; Ionov et al., 2013) frequently attributed to subcrustal arc conditions and possibly resulting from oxidation during passage of silicate melts. However, although Klyuchevskoy volcano has erupted by far the largest volume of high Mg-basalts, to date no modern studies have found xenoliths with clear mantle origins, although (Piip, 1956) did identify some Ol + Cpx aggregates at one location (Koloskov, 1999). The last indirect constraints on lithospheric compositions derive from isotopic signatures of lavas and their phenocrysts, which have been used to identify areas of metasomatized mantle (Dorendorf et al., 2000; Bindeman et al., 2004). Values of $\delta^{18} \mathrm{O}$ ranging from $5.8-7.1 \%$ in $\mathrm{Ol}$ and Opx phenocrysts from Klyuchevskoy lavas are interpreted as recording anomalously high mantle values formed via melting of upper mantle that was previously metasomatized by fluids derived from the downgoing slab. All of these studies highlight the complexity of the lithosphere through which magmas erupted at Tolbachik must pass and/or be stored within, providing a wide-range of materials to modify the geochemical complexity of the volcano's stratigraphy.

\subsection{Ostry Tolbachik and Plosky Tolbachik edifices}

Early volcanologists considered the Tolbachik volcanic massif as a single volcano simply referred to as Tolbachik (Konradi, 1925). Konradi argued that its eastern part had somehow subsided relative to its western part. Later it was suggested (Kulakov, 1936) that they were two closely situated but separate volcanic edifices, which should be referred to based on their distinctive morphologies (the western edifice is Ostry Tolbachik: "Ostry" means sharp in translation from Russian, and the eastern edifice is Plosky Tolbachik: "Plosky" means flat). These two names are now in common use.

Ostry Tolbachik volcano presently has an elevation of $3672.4 \mathrm{~m}$ a.s.l. (Fig. 7a), although it may have been higher in the past ( $3800 \mathrm{~m}$ a.s.l.) before being decapitated by a large landslide on its eastern side (Flerov and Melekestsev, 2013). Now, the collapsed wall is covered by a thick glacier. Ostry Tolbachik volcano is considered to be extinct and is being continuously modified by numerous gravitational collapses of different scales (Vlodavets, 1940; Piip, 1956). Large pyroclastic deposits are seen in erosional windows exposing the interior of the edifice (Fig. 7b), while the external flanks are mantled by lava flows. Most of the radial valleys surrounding the peak are partly filled by glaciers that descend from the summit.

Unlike Ostry Tolbachik, Plosky Tolbachik volcano is active now and often visited by scientists and as result its upper part and summit area 

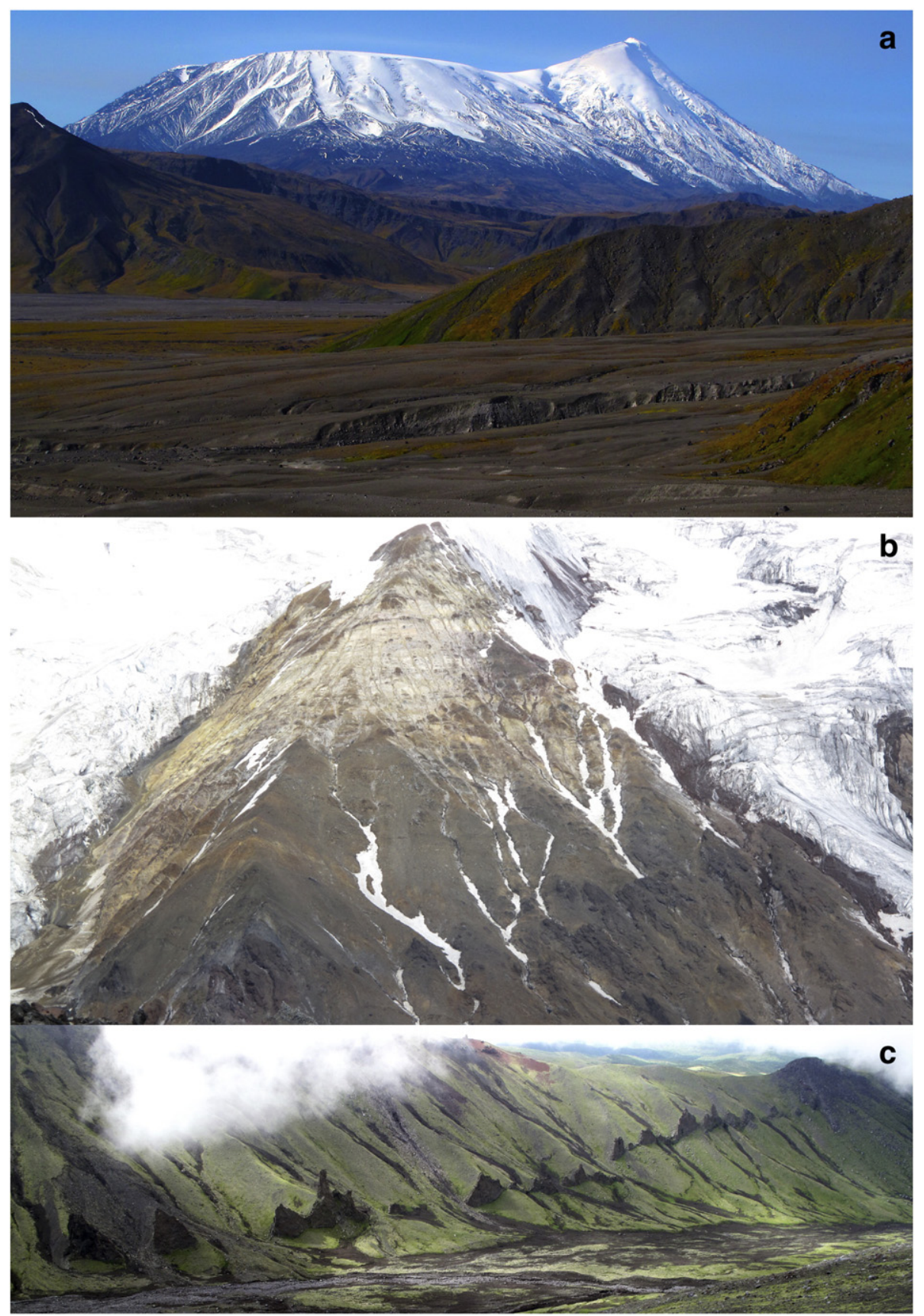

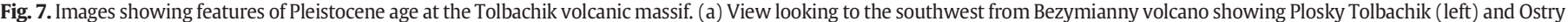

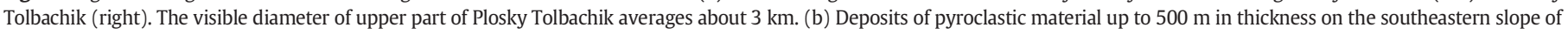
Ostry Tolbachik above Cheremoshny Glacier. (c) Dyke approximately $2 \mathrm{~km}$ long with azimuth $320^{\circ}$ in the Daechnaya valley on the northeast side of Ostry Tolbachik.

have been well studied (see also Section 4). The edifice has a flat summit hosting a Hawaiian-type pit crater/caldera with a diameter of about $3 \mathrm{~km}$ (Fig. 7a), which is completely filled by lava flows and ice. A smaller pit crater/caldera $1.8 \mathrm{~km}$ in diameter and $450 \mathrm{~m}$ deep has formed in the western part of the larger summit (Dvigalo et al., 1991), which itself contains a smaller pit crater/caldera that formed during the 19751976 eruption by subsidence. The smallest depression is about $400 \mathrm{~m}$ deep and has dimensions of 1615 by $1220 \mathrm{~m}$ (Fig. 8a). Geomorphological reconstructions suggest that this volcano was about $3900 \mathrm{~m}$ a.s.l. and probably was higher than Ostry Tolbachik (Flerov and Melekestsev, 2013). The origin of the large pit crater/caldera is still under debate; some authors suggest that this depression formed by subsidence due to removal of material from an underlying magma storage zone (Piip, 1954; Dvigalo et al., 1984), others have suggested it has an explosive origin (Ermakov and Vazheevskaya, 1973). A third hypothesis is that pit crater/caldera formation accompanied the collapse of the Povorotnaya mount block from the top of Plosky Tolbachik, $8 \mathrm{~km}$ to the north (Ponomareva et al., 2006). Numerous radial and ring dikes crosscut both edifices in all sectors (Fig. 7c).

A detailed geological and petrological map of the Tolbachik volcanic massif was made in the 1970's (Ermakov and Vazheevskaya, 1973; Ermakov, 1977). During this work it was determined that Plosky Tolbachik and Ostry Tolbachik are underlain by a common, older volcanic pedestal estimated to be Mid- to Late-Pleistocene in age. The pedestal appears to be the remnants of a shield volcano (the angle of the slopes is $3-5^{\circ}$ ) with a diameter of $22 \mathrm{~km}$ and $200-400 \mathrm{~m}$ of exposed sections at the $\mathrm{N}$ and NW sectors of the massif (Ermakov and Vazheevskaya, 1973). 

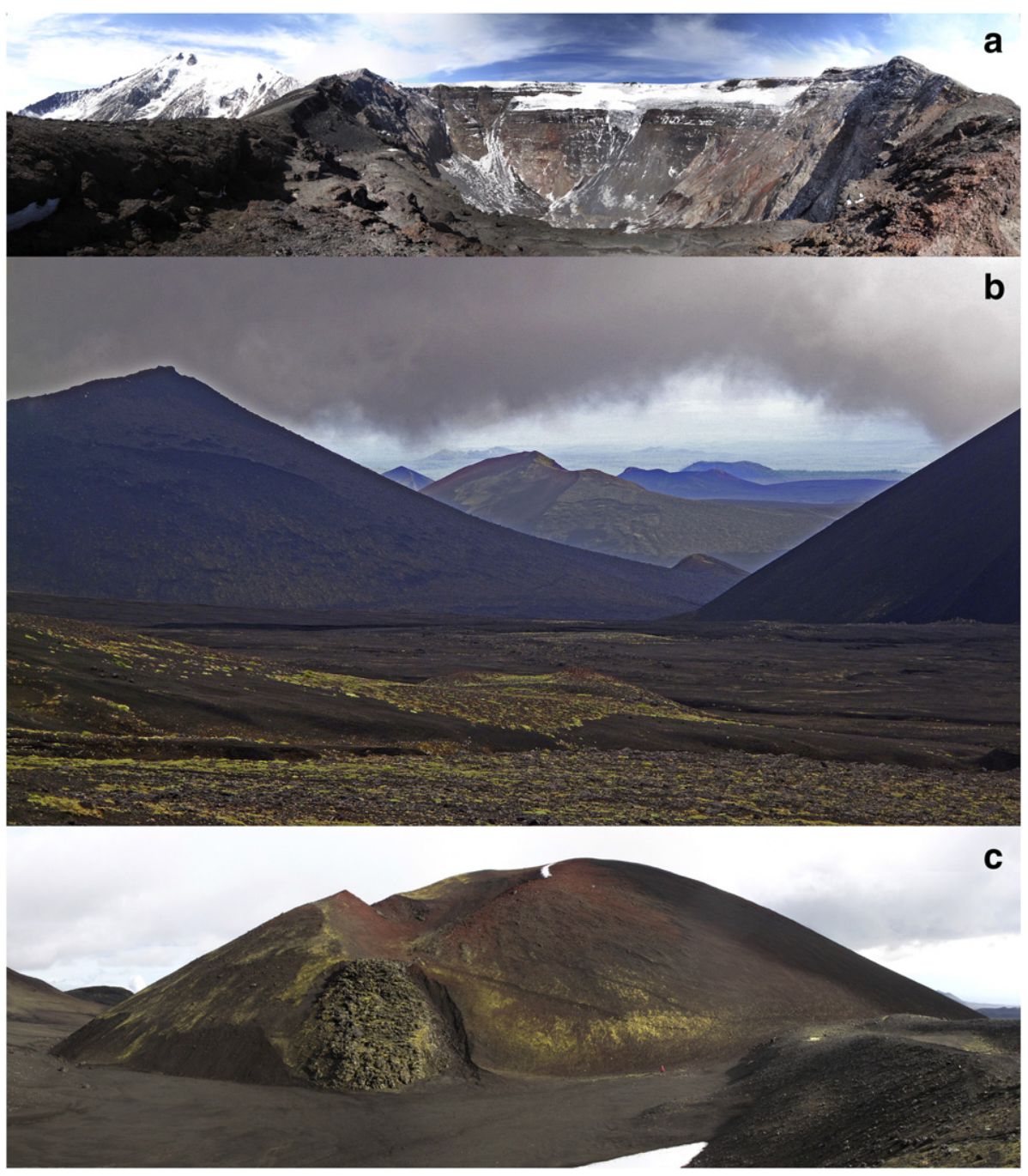

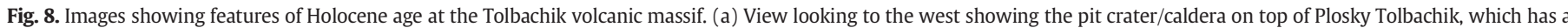

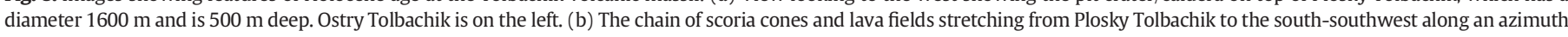

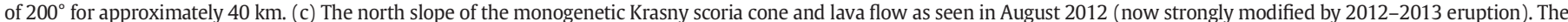
person (red coat) in front of the cone for scale.

\subsection{Zone of monogenetic cones and lava flow fields}

The zone of monogenetic cones and lava flow fields to the north and south of the Tolbachik volcanic massif comprises two rift-like branches separated by an $8 \mathrm{~km}$ cone-free area near the summit: a southern, more extensive one oriented SSW-NNE (azimuth $20^{\circ}-25^{\circ}$ ) and a northern one with a SW-NE direction (azimuth $40^{\circ}-55^{\circ}$, Figs. 1b, 9, e-Fig. 1). The length of the entire zone is about $60-70 \mathrm{~km}$ with a width of $13-$ $15 \mathrm{~km}$. However 80 percent of the scoria cones are concentrated in a narrower band with a width of 3-4 km, forming a volcanic ridge (Fig. 8b, Braitseva et al., 1984). This central part has a buried graben structure with a depth of 0.5-1.5 km (Balesta, 1991). The largest scoria cones are located in this narrow area and include Kleshnya, Peschanye Gorki, Alaid, Mount 1004, Mount Vysokaya, Lagerny, Krasny cone, and three northern cones formed during the 1975-1976 Northern Breakthrough. Scoria cones vary from $\sim 50-300 \mathrm{~m}$ in height. Based on the distribution of cones this zone contains several parallel fractures. The entire area, including the northern and southern branches, is covered by overlapping lava fields with a total area of about $985 \mathrm{~km}^{2}$ (Flerov and Melekestsev, 2013). During the 1975-1976 eruption the surface of this area was partly infilled by a large volume of airfall scoria (Fig. 8).
In the northern branch historical volcanism is absent. Past eruptions were concentrated along fissures 3-4 km in length in an elongated zone about $2 \mathrm{~km}$ wide (Braitseva et al., 1984). The southern branch is more extensive and contains several tens of cones. While the cones are most frequently composite cones (Kleshnya, Peschanye Gorky, Mount Vysokaya, Northern eruption cones of 1975-1976), some are single cones with well-shaped craters (Fig. 8c; Krasny cone, Alaid cone, Mount 1004, 1941 eruption cone; Southern Breakthrough cone of 1975-1976). Most of the cones have associated lava flows but it is not always possible to link lava flows to specific cones. Sometimes cones of different ages (e.g., Peschanye Gorky, Mount Vysokaya) are located in one chain. In this case the earlier cones frequently have been destroyed and covered by new lava flows from the later ones (e.g., Krasny cone and Naboko vent of 2012-2013). Older cones are also found on the southern branch of the Tolbachik zone of monogenetic cones, which are usually significantly eroded and only visible in partial outcropping because with time they have been covered by younger lavas, thick scoria layers, to the point where frequently their craters are no longer identifiable. Large fields (e.g., Maguskin field) have been covered by thick (more than $5 \mathrm{~m}$ ) scoria layers and the simultaneous existence of both 'àa and pahoehoe, which are characteristic features of Tolbachinsky Dol volcanism (Braitseva et al., 1984). 


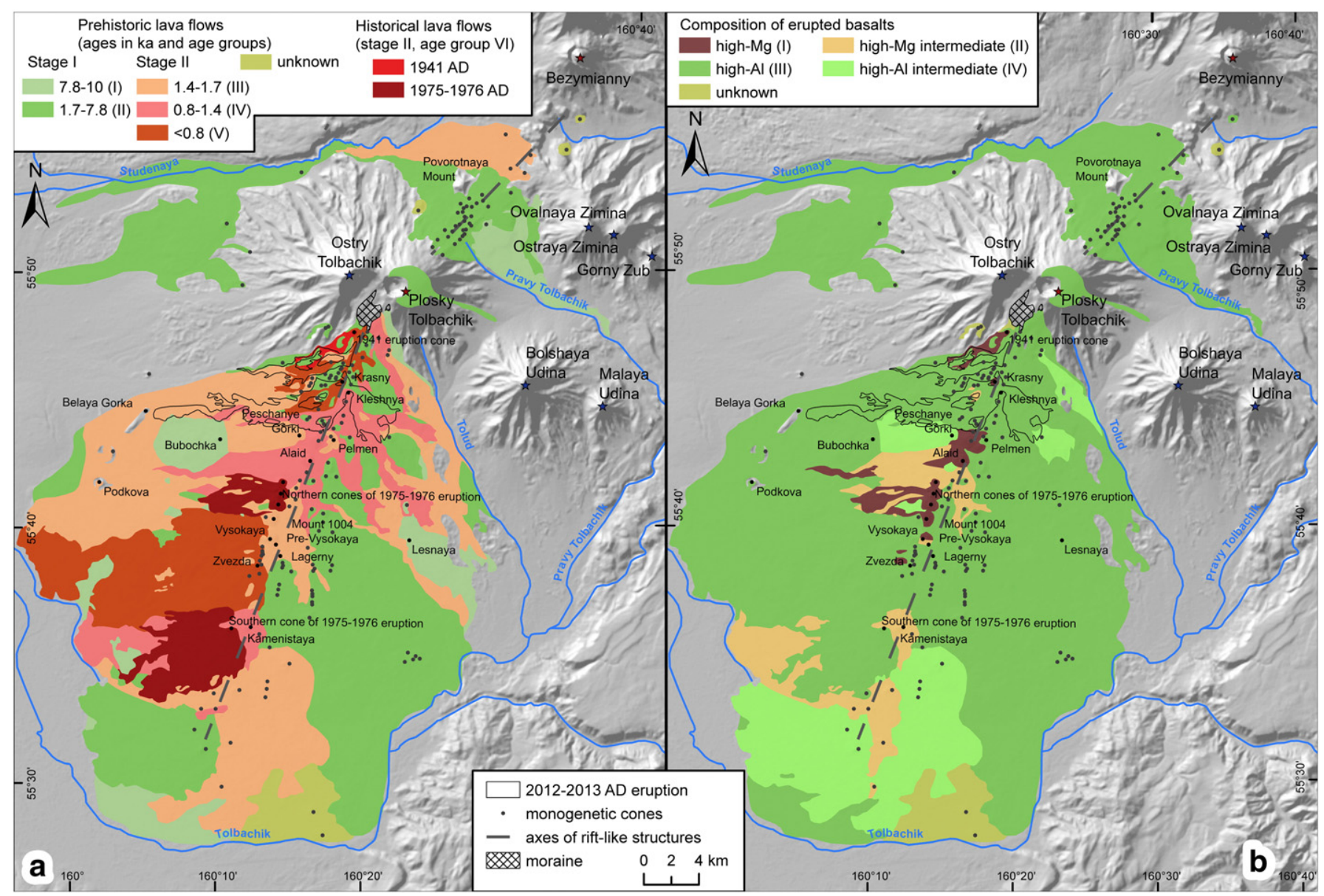

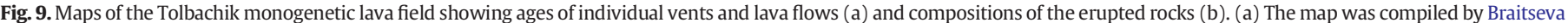

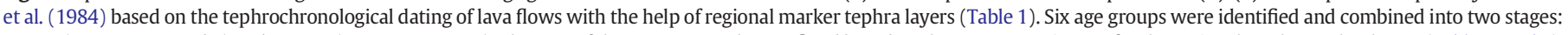

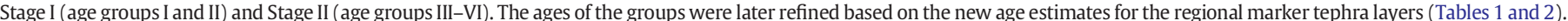

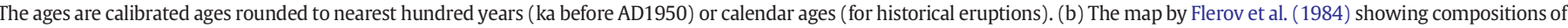
the erupted rocks. Roman numbers show the four rock composition types identified by the authors.

\section{Eruption history}

\subsection{Pleistocene}

Age determinations for the Pleistocene KGV rocks are few. The oldest known KGV lavas in its eastern and western parts are dated at 262-274 ka ( ${ }^{40} \mathrm{Ar} /{ }^{39} \mathrm{Ar}$; Calkins, 2004) and $306 \mathrm{ka}$ (K-Ar; Churikova et al., 2014). This narrow age range for lavas from different parts of the KGV suggests that all of the KGV volcanoes are underlain by the same lava basement. The pedestal of the Tolbachik volcanic massif has an age of $~ 86$ ka (K-Ar; Churikova et al., 2014).

Other age estimates for Pleistocene KGV volcanoes are based on their morphology and the stratigraphic relationships of their products with glacial deposits (Melekestsev et al., 1971; Braitseva et al., 1995). The age of Ostry Tolbachik and Plosky Tolbachik stratovolcanoes was estimated at 15-20 ka based on stratigraphic relationships with glacial deposits (Melekestsev et al., 1970; Flerov and Melekestsev, 2013). Some researchers argue that Ostry Tolbachik is older than Plosky Tolbachik (Piip, 1954; Flerov and Melekestsev, 2013) based on geomorphological reconstructions. Others suggest simultaneous growth of both edifices because the lava flows of both edifices are interlaid (Kulakov, 1936; Ermakov and Vazheevskaya, 1973).

A few Pleistocene scoria cones, which are partly eroded and surrounded by Holocene lavas, are located at the western margin of the Tolbachik zone of monogenetic cones (e.g., Podkova, Belaya Gorka). They may be related to Ploskye Sopki massif activity (Melekestsev et al., 1974).

\subsection{Holocene}

Volcanic activity in the Tolbachik zone of monogenetic cones started during the early Holocene (Braitseva et al., 1984). The formation of a large summit pit crater/caldera at Plosky Tolbachik stratovolcano might have been related to the onset of the zone activity (Braitseva et al., 1984). Subalkaline basalts, very similar in composition to those in the zone of monogenetic cones, form a 250-300 m thick intracaldera lava fill with a volume of $2.5 \mathrm{~km}^{3}$ (Braitseva et al., 1984). Numerous eruptions from the summit crater occurred during the Holocene and sometimes were accompanied by monogenetic activity (e.g., 1941 eruption; Piip, 1946).

The eruptive history within the zone was reconstructed in detail with the help of tephrochronological studies and radiocarbon dating (Braitseva et al., 1984). More than 60 Holocene monogenetic eruptions were identified.

The products of the initial activity within the Tolbachik zone of monogenetic cones are represented by cindery tephras with an approximate age of 10-11 ka (Braitseva et al., 1984). No lava flows or vents of this age have ever been found so they likely were buried under younger deposits. Lava flows of the Tolbachik zone of monogenetic cones were subdivided into six age groups and dated with the help of five regional marker tephra layers all of which were originally all attributed to Shiveluch volcano (Table V.2 in Braitseva et al., 1984). Further studies of these marker tephras resulted in confirmation of Shiveluch as the source for three tephras $\left(\mathrm{SH}_{2}, \mathrm{SH}_{3}\right.$, and $\left.\mathrm{SH}_{5}\right)$ and attribution of $\mathrm{SH}_{4}$ and $\mathrm{SH}_{6}$ tephras to Ksudach $\left(\mathrm{KS}_{1}\right)$ and Khangar (KHG) volcanoes, 
Table 1

Regional marker tephra layers in the deposits of the Tolbachik lava field.

\begin{tabular}{lllll}
\hline $\begin{array}{l}\text { Marker tephra } \\
\text { layers }\end{array}$ & $\begin{array}{l}\text { Source } \\
\text { volcano }\end{array}$ & $\begin{array}{l}\text { Age } \\
(\mathrm{ka})\end{array}$ & $\begin{array}{l}\text { Old codes of marker } \\
\text { tephra layers }\end{array}$ & $\begin{array}{l}\text { Old age estimates } \\
\left({ }^{14} \mathrm{C} \text { ka }\right)\end{array}$ \\
\hline $\mathrm{SH}_{2}$ & Shiveluch & 0.8 & $\mathrm{SH}_{2}$ & $0.9-1.0$ \\
$\mathrm{SH}_{3}$ & Shiveluch & 1.4 & $\mathrm{SH}_{3}$ & $1.4-1.5$ \\
$\mathrm{KS}_{1}$ & Ksudach & 1.7 & $\mathrm{SH}_{4}$ & 2.0 \\
$\mathrm{SH}_{5}$ & Shiveluch & 1.9 & $\mathrm{SH}_{5}$ & $2.5-2.6$ \\
$\mathrm{KHG}$ & Khangar & 7.8 & $\mathrm{SH}_{6}$ & 7.5 \\
\hline
\end{tabular}

Note: Age in the third column is calibrated ${ }^{14} \mathrm{C}$ age rounded to nearest hundred years (weighted mean of all age estimates for each layer; ka before AD1950) (Ponomareva et al., 2015). Old codes and age estimates (two last columns) are from (Braitseva et al., 1988). Age in the last column is average non-calibrated ${ }^{14} \mathrm{C}$ age.

respectively (Tables 1 and 2; Braitseva et al., 1997). Ages of all five of the marker tephras were refined based on numerous ${ }^{14} \mathrm{C}$ dates (Braitseva et al., 1997; Bazanova and Pevzner, 2001; Ponomareva et al., 2007b; Ponomareva et al., 2015). New and old marker layer codes and ages for these marker layers are presented in Table 1. We retain all of the six groups of lava flows defined by (Braitseva et al., 1984). Their age estimates, however, are refined according to new age estimates for marker tephras.

The oldest lavas of the Tolbachik zone of monogenetic cones (group I, 7.8-10.0 ka) are found closer to the margins of the Tolbachik lava field (Fig. 9, e-Fig. 1). They are covered with a 3-4 m thick soil-pyroclastic sequence, the lower part of which either contains KHG marker tephra or is stratigraphically close to the latter. Only two scoria cones of this age, Bubochka and Lesnaya, are still preserved in topography. Other vents and most of the lava flows of this group are covered with younger lavas, and occur only in disparate "windows". Group II (1.7-7.8 ka) includes the lava flows overlain by $\mathrm{SH}_{5}$ and/or $\mathrm{KS}_{1}$ tephras. These lavas are well expressed along the Tolbachik zone of monogenetic cones (Fig. 9a).

Groups I and II are combined into Stage I, which was dominated by eruptions of sub-alkaline basalts (Table 2, see also Section 5). The average magma production rate during Stage I was $\sim 17 \times 10^{6}$ tons per year (Braitseva et al., 1984), and both northern and southern branches of the Tolbachik zone of monogenetic cones were active (Fig. 9a). Although most of the vents formed along a 13-15 km wide belt, by the end of the Stage I the belt had narrowed.

The onset of Stage II at 1.7 ka was marked by the first eruptions of high-Mg medium-K basalts (see Section 5) and other dramatic changes in the character of volcanism within the Tolbachik zone of monogenetic cones (Fig. 9b). The magma production rate increased up to $\sim 25 \times 10^{6}$ tons per year, the vents concentrated within a $3-4 \mathrm{~km}$ wide belt, eruptive activity moved mainly to the southern branch of the Tolbachik monogenetic lava field, and the larger scoria cones started to form. Between 1.4-1.7 ka (age group III) several large cones and their lava flows were formed including Mount 1004, Mount PreVysokaya, Lagerny, and Pelmen. These lavas are covered with $\mathrm{SH}_{3}$ and underlain by $\mathrm{KS}_{1}$ marker tephras (Tables 1 and 2). The next age group (group IV, 0.8-1.4 ka) includes Kamenistaya, Alaid, Peschanye Gorki, and Kleshnya cones. Lavas of this group fit stratigraphically between the $\mathrm{SH}_{2}$ and $\mathrm{SH}_{3}$ marker tephras. Vysokaya, Krasny, Zvezda cones and their lava flows (age group $\mathrm{V}$ ) are younger than the $\mathrm{SH}_{2}$ marker tephra $(\sim 0.8 \mathrm{ka})$. Simultaneous eruptions from Zvezda and the Plosky Tolbachik summit might have been observed by Stepan Krasheninnikov in 1739-1740 (Krasheninnikov, 1755; Braitseva et al., 1984).

\subsection{Historical eruptions}

During historical time numerous, mainly explosive eruptions have been documented on the summit of Plosky Tolbachik volcano (e.g., 1740, 1769, 1788-1790, 1793, 1904, 1931, 1937). Two of them, in 1740 and in 1904, were accompanied by lava flows (Vlodavets and Piip, 1957). However, the first systematic studies of the Plosky Tolbachik summit were not conducted until 1935 (Kulakov, 1936) when the Kamchatka volcano observatory was formed (Fig. 2). Since that time all eruptions have been documented by research groups who climbed to the top of the volcano after each eruption and documented all changes in summit shape and fumarole activity (e.g., Vlodavets, 1937, 1940; Piip, 1946, 1954; Popkov, 1946; Menyailov, 1953; Zavaritsky et al., 1954; Sirin and Farberov, 1963; Markhinin, 1964; Pronin et al., 1970; Kirsanov and Ponomarev, 1974). The characteristic features of the Plosky Tolbachik summit eruptions are the periodic presence and changes in levels of lava lakes inside the pit crater/caldera. During 1936-1977 the pit crater/caldera of the volcano increased 4-6 times in all dimensions and the volume of the depression increased from $0.01 \mathrm{~km}^{3}$ to $0.347 \mathrm{~km}^{3}$ (Dvigalo et al., 1984, 1991).

In addition to the activity in the summit of the volcano, two flank eruptions, in 1941 and in 1975-1976, have been observed and studied in detail. Both these eruptions were accompanied by summit activity. The 1941 eruption was short-lived but very intensive. It occurred on the southern slope of Plosky Tolbachik volcano at an elevation of $1900 \mathrm{~m}$ a.s.l. and was $4.5 \mathrm{~km}$ from the volcano's summit. This eruption was preceded by 18 months of summit activity including fumaroles and explosions at a lava lake in the bottom of the pit crater/caldera. The 1941 eruption was the last event of 1939-1941 period of activity. During only 7 days of eruption (7-14 May) a new scoria cone formed as well as a lava flow $5 \mathrm{~km}$ in length. This eruption was observed by people from the surrounding villages (30-50 km from the eruption), and was described in detail two months later by (Piip, 1946). I.V. Melekestsev estimated that the total volume of this eruption was $\sim 0.1 \mathrm{~km}^{3}$ of which $70 \%$ was ash- to lapilli-size scoria (Braitseva et al., 1984).

The 1975-1976 eruption lasted for more than 17 months and was closely observed and studied by researchers from the Institute of Volcanology of Russian Academy of Sciences under the leadership of S.A. Fedotov. It has commonly been referred to as the "Great Tolbachik Fissure Eruption" (Fedotov and Markhinin, 1983). The main results of the continuous and detailed research were published less than a decade later (Fedotov and Markhinin, 1983; Fedotov, 1984). This eruption was

Table 2

Age groups of volcanic rocks of the Tolbachik monogenetic scoria cones.

\begin{tabular}{|c|c|c|c|c|}
\hline Stage & Age group & Age & Rock composition & Stratigraphic position \\
\hline \multirow[t]{6}{*}{ II } & VI (Historical) & 2012-2013 & Basalt type III and basaltic andesite & Above modern soil \\
\hline & & 1975-1976 & Basalt types I and III & \\
\hline & & 1941 & Basalt type I & \\
\hline & $\mathrm{V}$ & $<0.8$ & Basalt types I and III & Above $\mathrm{SH}_{2}$ \\
\hline & IV & $0.8-1.4$ & Basalt types I-III & Between $\mathrm{SH}_{2}$ and $\mathrm{SH}_{3}$ \\
\hline & III & $1.4-1.7$ & Basalt types I-IV & Between $\mathrm{SH}_{3}$ and $\mathrm{KS}_{1}$ \\
\hline \multirow[t]{3}{*}{ I } & IIb & $1.7-1.9$ & Basalt type III & Between $\mathrm{KS}_{1}$ and $\mathrm{SH}_{5}$ \\
\hline & Ila & $1.9-7.8$ & Basalt type III-IV & Between $\mathrm{SH}_{5}$ and $\mathrm{KHG}$ \\
\hline & I & $7.8-10$ & Basalt type III & Under KHG \\
\hline
\end{tabular}

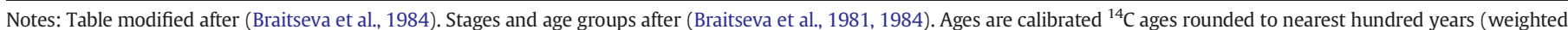

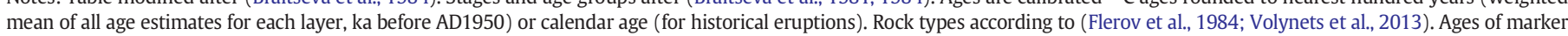
tephra layers after (Ponomareva et al., 2015). Codes for marker tephra layers according to (Braitseva et al., 1997). 
the largest historical basaltic eruption in Kurile-Kamchatka arc and one of the six largest historic fissure eruptions globally. The total erupted volume during 1975-1976 was $2.17 \mathrm{~km}^{3}$ (including $1.19 \mathrm{~km}^{3}$ of lava, $0.71 \mathrm{~km}^{3}$ of tephra, and scoria cones with a total volume of $0.27 \mathrm{~km}^{3}$ ), the total erupted mass was $3.81 * 10^{6}$ tons (Braitseva et al., 1984) and the area covered by scoria and lava exceeded $1000 \mathrm{~km}^{2}$ (Fedotov et al., 1991).

During this eruption two active areas, the Northern Breakthrough and the Southern Breakthrough, erupted lavas and scoria of two different compositions, and created four new scoria cones. The formation of each cone started with the opening of a fissure (or series of fissures) that produced tephra along the fissure from a "curtain of fire" before the activity was localized to the cone and lava flows began to form. The eruption started at the Northern Breakthrough, on 6 July 1975 along a fissure $250-300 \mathrm{~m}$ long, located at an elevation of $880 \mathrm{~m}$ a.s.l. and $18 \mathrm{~km}$ to the south-southwest from the Plosky Tolbachik summit. It quickly became localized at cone number 1 , which produced an eruptive plume more than $6 \mathrm{~km}$ high (Fig. 9). The eruption mainly produced pyroclastic material until 27 July after which lava flows started and continued to 9 August, when the activity of cone 1 stopped. Twelve hours later, a second fissure began to open at an elevation of $750-800 \mathrm{~m}$ a.s.l. to the NNE of cone 1 , which leads to the formation of cone 2 . The eruptions from this cone were more effusive and produced a thick lava flow $5 \mathrm{~km}$ long, $1.5 \mathrm{~km}$ wide and a lava front thickness up to $80 \mathrm{~m}$ (Fedotov and Masurenkov, 1991). On 16-17 August cone 3 started to grow and on 21-22 August cone 4, which was later completely covered by volcanic material of the same eruption, started to grow to the SW of cone 3. However, from 25 August onward all of the eruptive activity became localized at cone 2 . By 15 September the eruption at the Northern Breakthrough vents had stopped after 72 days of activity. The lava of this eruption covered an area of $8.86 \mathrm{~km}^{2}$ with lava volume of $0.223 \mathrm{~km}^{3}$ (Fedotov and Markhinin, 1983; Fedotov, 1984; Fedotov et al., 1991).

Two days later, on 17 September, the second phase of the eruption began with the initiation of activity at the Southern Breakthrough, which started with the opening of a $600 \mathrm{~m}$ long fissure approximately $28 \mathrm{~km}$ to the south-southwest from the Plosky Tolbachik summit at an elevation $380 \mathrm{~m}$ a.s.l. This eruption continued for 450 days until 10 December 1976. It was more effusive compared to the eruption at the Northern Breakthrough, formed only one scoria cone, and lava of this eruption covered an area of $35.9 \mathrm{~km}^{2}$ with $\sim 1 \mathrm{~km}^{3}$ of lava. The Southern Breakthrough was a Hawaiian-style eruption with fluid lavas.

Before the 1975-1976 eruption, the summit depression of Plosky Tolbachik volcano was 350-400 $\mathrm{m}$ in diameter, 150-200 m deep, and located in the western part of the second pit crater/caldera. The 1975-1976 eruption was accompanied by weak activity on the summit of Plosky Tolbachik volcano; small explosions started at the summit 8 days before the fissure opening and several explosions occurred during the first three months of the eruption. In the beginning of 1975-1976 eruption large-scale subsidence and collapses accompanied by ash clouds were documented at the summit of the volcano. A second, large series of collapses was connected to the beginning of Southern Breakthrough in September 1975. A lake with a water volume about $0.005 \mathrm{~km}^{3}$ formed during this eruption as result of melting of ice from the summit glacier. The size of the new pit crater/caldera after the eruption was 1615 by $1220 \mathrm{~m}$ with a depth of $404 \mathrm{~m}$. A small temporary lake existed inside for short period of time after the eruption (Dvigalo et al., 1984, 1991).

\section{Petrology}

\subsection{Petrography}

The pedestal of the Tolbachik volcanic massif comprises two suites of rocks. The lower part is dominated by $\mathrm{Cpx}$-phyric and Ol-Px-phyric basalts, while the upper part is dominated by Pl-phyric basalts and basaltic andesites (Ermakov and Vazheevskaya, 1973; Ermakov, 1977).
The rocks of the massif itself, which includes both Plosky Tolbachik and Ostry Tolbachik stratovolcanoes, are petrographically diverse. The lower parts comprise mainly $\mathrm{Cpx}-\mathrm{Opx}-\mathrm{Pl}$ basalts and $\mathrm{Pl}$-free basalts, but in the middle and upper parts Pl-rich basalts and basaltic andesites are abundant. Two-Px and Hb-bearing andesites and basaltic andesites have also been found in both edifices (Piip, 1956; Ermakov, 1977). Both stratovolcanoes are also cut by numerous dikes, which are most frequently $\mathrm{Px}-\mathrm{Pl}$ basaltic andesites locally with $\mathrm{Hb}$ or $\mathrm{Ol}$, megacrystic $\mathrm{Pl}$ and $\mathrm{Cpx}$ basalts, $\mathrm{Ol}-\mathrm{Pl}$, or Px-bearing basalts. Some dikes on the northwestern slope of Ostry Tolbachik are Ol-Px-rich rocks with Ol and Px phenocrysts up to $1.5 \mathrm{~cm}$ in size. Opx and Mt are present in minor amounts in all rocks. The textures of rocks are mainly finegrained, porphyritic and sub-aphyric. The sequence of crystallization varies. The ground mass has intersertal texture with microlites and can include rare pigeonite and quartz (Flerov and Melekestsev, 2013).

Based on the mineralogical and petrological features and on $\mathrm{MgO} /$ $\mathrm{Al}_{2} \mathrm{O}_{3}$ ratios (see also Section 5.3) in basalts from the Tolbachik zone of monogenetic cones, all rocks were divided into four types (Flerov et al., 1984): high-Mg basalts, subalkaline high-K trachybasalts, and two intermediate types. Petrographically they also range from high$\mathrm{Mg}, \mathrm{Ol}-\mathrm{Px}$-phyric and subaphyric basalts to subalkaline megacrystic Pl basalts with a complete gradation in between. Subaphyric lavas have a fine-grained groundmass with rare phenocrysts of $\mathrm{Ol}, \mathrm{Cpx}$, and sometime $\mathrm{Pl}$ varying from $0.2-0.8 \mathrm{~mm}$ in maximum dimension, but rarely up to $8 \mathrm{~mm}$. Textures vary from dense to vesicular. The groundmass comprises the same minerals but with higher abundances of $\mathrm{Pl}, \mathrm{Sp}$, Mt, and volcanic glass of different colors (Flerov et al., 1984).

Megacrystic Pl basalts with large (up to $2 \mathrm{~cm}$ ) Pl phenocrysts are a characteristic feature of the zone of monogenetic cones at the Tolbachik volcanic massif. They dominate the northern branch of this zone, fill the pit crater/caldera of Plosky Tolbachik summit, and are widely distributed throughout the southern part of the zone. They are very vesicular and comprise of mainly $\mathrm{Ol}, \mathrm{Cpx}$ and $\mathrm{Pl}$, with $\mathrm{Pl}$ dominant (up to 20 modal percent). $\mathrm{Ol}$ and $\mathrm{Cpx}$ normally are $1-2 \mathrm{~mm}$ in size and they compose less than $5 \%$ of rock. Opx is usually absent or present in very low abundances (less than 1\%). The groundmass is vitrophyric and more glass-rich than any other Tolbachik rocks. These lavas are also characterized by highly variable vesicularity, which varies from 10 to $55 \%$. Pl megacrysts can be found in lavas, bombs and as separate lapilli, where multiple Pl twins form spherical aggregates up to $4 \mathrm{~cm}$ in diameter. Such lapilli are often found around monogenetic cones and in the summit area (Kirsanov and Ponomarev, 1974; Flerov et al., 1984).

\subsection{Mineralogy}

\subsubsection{Mineralogy of erupted and post-eruption products}

The main rock-forming minerals in all lavas of the stratovolcanoes and monogenetic cones are $\mathrm{Ol}, \mathrm{Cpx}$ and $\mathrm{Pl}$. Opx exists in rocks of the stratovolcanoes, but it is very rare in the monogenetic cones. The minerals in basalts and basaltic andesites from Ostry Tolbachik and Plosky Tolbachik have very similar compositions: olivine ranges from $\mathrm{FO}_{79-58}(\mathrm{CaO}=$ $0.1-0.25 \%$ ), plagioclase varies from $\mathrm{An}_{92-52}$ and $\mathrm{Or}_{0.41-2.56}$, clinopyroxene is diopsidic-augite with $\mathrm{Mg \#}_{87-65}$, and $\mathrm{Sp}$ is titanomagnetite (Table 3; Flerov et al., 2015).

Most of the mineralogical data for the basalts of the monogenetic cones come from the investigations on samples from the 1975-1976 eruption. The high-Mg basalts and also intermediate rock types of the monogenetic cones have a rather mafic mineral association: Ol varies from $\mathrm{Fo}_{85-90}(\mathrm{CaO}=0.07-0,49 \%), \mathrm{Cpx}$ is diopside and diopsidic augite with $\mathrm{Mg \#} \#_{76-88}$, and $\mathrm{Pl}$ is labradorite with $\mathrm{An}_{74-55}$ and $\mathrm{Or}_{1.78-4.40}$, Sp is chromian picotite with $\mathrm{Cr}_{2} \mathrm{O}_{3}$ up to 54 wt.\% (Flerov et al., 1984). The mineral compositions in subalkaline rocks are systematically different from both high-Mg basalts and rocks from the stratovolcanoes: Ol has a narrower range of $\mathrm{Fo}_{76-69},(\mathrm{CaO}=0.17-0.40 \%), \mathrm{Pl}$ is labradorite with $\mathrm{An}_{73-52}$ and $\mathrm{Or}_{0.8-3.1}, \mathrm{Cpx}$ is augite with $\mathrm{Mg \#}{ }_{82-66}$, and $\mathrm{Sp}$ is titanomagnetite (Table 3). Large Pl megacrysts, which are frequently 
Table 3

Mineral composition and P-T conditions of the crystallization of the main rock types at Tolbachik volcanic massif.

\begin{tabular}{|c|c|c|c|c|c|c|c|c|}
\hline Location & Rock type & Mineral paragenesis & $\mathrm{T}_{\text {cryst }},{ }^{\circ} \mathrm{C}$ & $\begin{array}{l}P_{\text {cryst }} \\
\text { kbar }\end{array}$ & Fugacity & $\mathrm{CO}_{2}$ & $\begin{array}{l}\mathrm{P}_{\mathrm{H} 2 \mathrm{O}} \\
\text { kbar }\end{array}$ & References \\
\hline $\begin{array}{l}\text { Tolbachik monogenetic } \\
\text { lava field }\end{array}$ & $\begin{array}{l}\text { High-Mg middle-K, stage } \\
1 \text { of crystallization }\end{array}$ & $\begin{array}{l}\mathrm{Fo}_{90-85}+\mathrm{Cpx}_{12-20} \pm \mathrm{An}_{65-75}+ \\
\mathrm{Sp}_{1}-\mathrm{Sp}_{2}\end{array}$ & $1260-1200$ & $4-7$ & $10^{-6}-10^{-6.5}$ & High & 0.001 & $\begin{array}{l}\text { Flerov et al., 1980; Lukanin et al., } \\
\text { 1980; Romanchev and Flerov, } 1980\end{array}$ \\
\hline $\begin{array}{l}\text { Tolbachik monogenetic } \\
\text { lava field }\end{array}$ & $\begin{array}{l}\text { High-Mg middle-K, stage } \\
2 \text { of crystallization }\end{array}$ & $\begin{array}{l}\mathrm{Fo}_{85}+\mathrm{Cpx}_{20-21} \pm \mathrm{An}_{65-62}+ \\
\mathrm{Sp}_{2-\mathrm{Sp}_{4}}\end{array}$ & $1195-1165$ & 1 & $10^{-5.5}-10^{-6}$ & High & 0.001 & $\begin{array}{l}\text { Flerov et al., 1980; Lukanin et al., } \\
\text { 1980; Romanchev and Flerov, } 1980\end{array}$ \\
\hline $\begin{array}{l}\text { Tolbachik monogenetic } \\
\text { lava field }\end{array}$ & High-K trachybasalt & $\begin{array}{l}\mathrm{Fo}_{76-72}+\mathrm{Cpx}_{26-30}+\mathrm{An}_{44-80}+ \\
\mathrm{Sp}_{3} \pm \mathrm{Opx}_{24-28}+\mathrm{Pig}_{24}\end{array}$ & $1190-1140$ & $3-1$ & $10^{-7}-10^{-7.5}$ & Low & 0.5 & $\begin{array}{l}\text { Flerov et al., 1980; Lukanin et al., } \\
\text { 1980; Romanchev and Flerov, } 1980\end{array}$ \\
\hline Stratovolcano & Middle-K calcalkaline & $\begin{array}{l}\mathrm{Fo}_{58-79}+\mathrm{Cpx}_{13-33}+\mathrm{An}_{92-78} \\
\text { and } \\
\mathrm{An}_{87-51}+\mathrm{Sp}_{4}+\mathrm{Opx}_{23-34}\end{array}$ & $1070-1200$ & $2.6-3.3$ & - & - & - & Flerov et al., 2015 \\
\hline
\end{tabular}

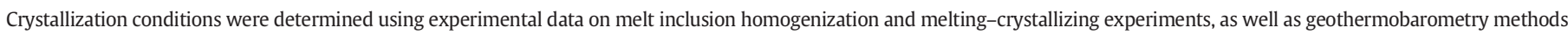

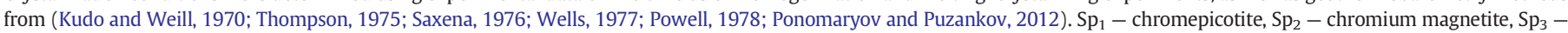
chromium titanomagnetite, $\mathrm{Sp}_{4}$ - chromium-free titanomagnetite. Minals in pyroxenes were calculated as $\mathrm{Fe} /(\mathrm{Fe}+\mathrm{Mg})$.

found in subalkaline rocks, can be more calcic and variable in composition with $\mathrm{An}_{80-44}$. Orthopyroxene is rather similar and represented by the bronzite-hypersthene series with $\mathrm{Mg \#}_{23-34}$. Mineral compositions of the intermediate types of rocks are highly variable as they include minerals from different associations, which are generally not in equilibrium; the fields of these rocks overlap with all groups on binary composition diagrams.

Recent research shows that the minerals from the stratovolcanoes and high-K lavas of type III from the monogenetic cones are rather different: Ol from high-K lavas is enriched in $\mathrm{CaO}, \mathrm{Pl}$ is enriched in Or component and $\mathrm{Cpx}$ is enriched in titanium compared to $\mathrm{Ol}$ from stratovolcanoes rocks (Flerov et al., 2015). Spinels from high-K basalts are depleted in iron, but enriched in chromium compared to spinels from stratovolcanoes. The groundmasses of high-K lavas are also enriched in alkalies compared to all other rocks of the Tolbachik volcanic massif. Phenocrysts from all associations can be found with each other as disequilibrium phases, which is consistent with extensive magma mixing occurring in the magma storage zones beneath the Tolbachik volcanic massif (Flerov et al., 2015). This also is supported by the existence of chemically different matrix glasses in some samples.

The 1975-1976 eruption was very productive with respect to posteruption minerals formation and during the 35 years after this eruption more than 120 exhalation minerals have been identified, 32 of which were new (e-Table 2; Vergasova and Filatov, 2012) and 52 of which are the first reported occurrences in Kamchatka (e-Table 2). The exhalation minerals mainly consist of lithophile (K, Na, Mg, Ca, $\mathrm{Al}, \mathrm{Si}, \mathrm{Rb}, \mathrm{Cs}, \mathrm{P}$, $\mathrm{V}, \mathrm{C}, \mathrm{O}, \mathrm{F}, \mathrm{Cl}$ ) and chalcophile ( $\mathrm{S}, \mathrm{Cu}, \mathrm{Zn}, \mathrm{Pb}, \mathrm{As}, \mathrm{Se}, \mathrm{Au}, \mathrm{Bi}, \mathrm{Te}$ ) elements, with lesser concentrations of Fe and Mo (e-Table 2). All of the new minerals can be divided into one of 7 groups: fluorides, chlorides, oxochlorides, carbonates, arsenates, vanadates, sulfates and oxysulfates, selenites, and oxyselenites. Most of them are anhydrous. According to experimental data, the metals in Tolbachik fumaroles can be transported as chlorides, oxochlorides, oxo-centered complexes $\mathrm{OA}_{4}$, and also can be transported in water-free conditions. Copper appears to be closely connected to $\mathrm{K}$ and $\mathrm{Na}$, and is transported with them as a gas phase forming copper ore deposits by $\mathrm{Cu}$-rich exhalation minerals in the crater cone areas (Naboko and Glavatskikh, 1983; Vergasova et al., 2007).

\subsubsection{Constraints on crystallization conditions}

Romanchev and Flerov (1980) studied melt inclusions from samples of the 1975-1976 eruption and found that high-Mg melts crystallized at higher $\mathrm{CO}_{2}$ pressure while the subalkaline high-K rocks did not contain high-density $\mathrm{CO}_{2}$ inclusions, which suggests a greater depth of crystallization for the high-Mg lavas (Table 3). Temperatures of crystallization estimated from homogenization experiments show that high-Mg basalt crystallized at higher temperatures than subalkaline high-K lavas, $1260-1180{ }^{\circ} \mathrm{C}$ and $1190-1140{ }^{\circ} \mathrm{C}$, respectively. Megacrystic plagioclase crystallized under the temperatures of around $1150{ }^{\circ} \mathrm{C}$ (Romanchev and
Flerov, 1980). The crystallization temperatures estimated from mineral compositions for rocks from the stratovolcanoes show rather lower temperatures $-1150-1200{ }^{\circ} \mathrm{C}$ at dry conditions and $1070-1090{ }^{\circ} \mathrm{C}$ at water contents of 1-3\% (Flerov et al., 2015). The intermediate rocks show highly nonequilibrium conditions. However, the experiments on melting and crystallization show rather similar crystallizations temperatures for both high-Mg and subalkaline high-K rocks, $1195-1165{ }^{\circ} \mathrm{C}$ and $1185-1155^{\circ} \mathrm{C}$, respectively (Lukanin et al., 1980).

The pressures estimated from mineral compositions for high-Mg lavas of the 1975-1976 Northern Breakthrough eruption record decreasing pressures during crystallization from $0.4-0.5 \mathrm{GPa}(13-20 \mathrm{~km}$ depth) for $\mathrm{Ol}$ and Px to less than $0.1 \mathrm{GPa}$ (less than $3 \mathrm{~km}$ depth) for Pl (Lukanin et al., 1980; Romanchev and Flerov, 1980). The phenocrysts from the lavas of the 1975-1976 Southern Breakthrough eruption crystallized at water pressures of about $0.05 \mathrm{GPa}$. The calculated crystallization pressures from mineral compositions for stratovolcano rocks are $0.4-0.75 \mathrm{GPa}$, which corresponds to depths of about $12-25 \mathrm{~km}$ (Flerov et al., 2015).

\subsection{Major elements}

Major element compositional data for the Tolbachik pedestal rocks and Ostry Tolbachik and Plosky Tolbachik stratovolcano lavas are limited and spatially scattered (e.g., Fig. 1 in Flerov and Melekestsev, 2013). However, a combination of these data and microprobe analyses of matrix glasses shows that lavas from the stratovolcanoes and monogenetic cones are systematically different. Changes in petrochemistry and geochemistry have been attributed to the change in volcanic activity from central vent-type volcanism to more areally extensive volcanism (Ermakov and Vazheevskaya, 1973; Flerov and Melekestsev, 2013).

Based on $\mathrm{MgO} / \mathrm{Al}_{2} \mathrm{O}_{3}$ ratios, the basalts from the Tolbachik zone of monogenetic cones have been divided into four types (Fig. 9b; Flerov et al., 1984): high- $\mathrm{Mg}$ (type $\mathrm{I}, \mathrm{MgO} / \mathrm{Al}_{2} \mathrm{O}_{3}>0.58$ ), intermediate magnesian (type II, $0.45<\mathrm{MgO} / \mathrm{Al}_{2} \mathrm{O}_{3}<0.58$ ), high-Al (type III, $0.32<\mathrm{MgO}$ / $\mathrm{Al}_{2} \mathrm{O}_{3}<0.45$ ) and intermediate aluminum (type IV, $\mathrm{MgO} / \mathrm{Al}_{2} \mathrm{O}_{3}<$ 0.32 ). Types I and II are middle-K, while type IV and most of samples of type III (except few of middle-K lavas) are high-K trachybasalts. High-Mg lavas are enriched in $\mathrm{MgO}, \mathrm{CaO}$ and $\mathrm{MgO} / \mathrm{Al}_{2} \mathrm{O}_{3}$ while high- $\mathrm{K}$ trachybasalts are enriched in $\mathrm{FeO}, \mathrm{CaO}, \mathrm{Al}_{2} \mathrm{O}_{3}, \mathrm{TiO}_{2}, \mathrm{~K}_{2} \mathrm{O}, \mathrm{Na}_{2} \mathrm{O}, \mathrm{P}_{2} \mathrm{O}_{5}$ and $\mathrm{K}_{2} \mathrm{O} / \mathrm{Na}_{2} \mathrm{O}$. Both series of rocks are depleted in $\mathrm{SiO}_{2}$ and enriched in $\mathrm{FeO}$ and $\mathrm{TiO}_{2}$ compared to all other CKD volcanoes (Fig. 10). The most common rocks are high-Mg basalts (type I) and high-K trachybasalts (type III), which are connected by types II and IV (Braitseva et al., 1984; Flerov et al., 1984).

During the Holocene all types of rocks were repeatedly erupted. Within age group I (7.8-10.0 ka; see Section 4.2 and Fig. 9a) only basalts of type III were erupted. During the next time period (1.7-7.8 ka), 92.5\% of the erupted products were also high-K trachybasalts (type III), but the rest were lavas of intermediate types II and IV. The first high-Mg 

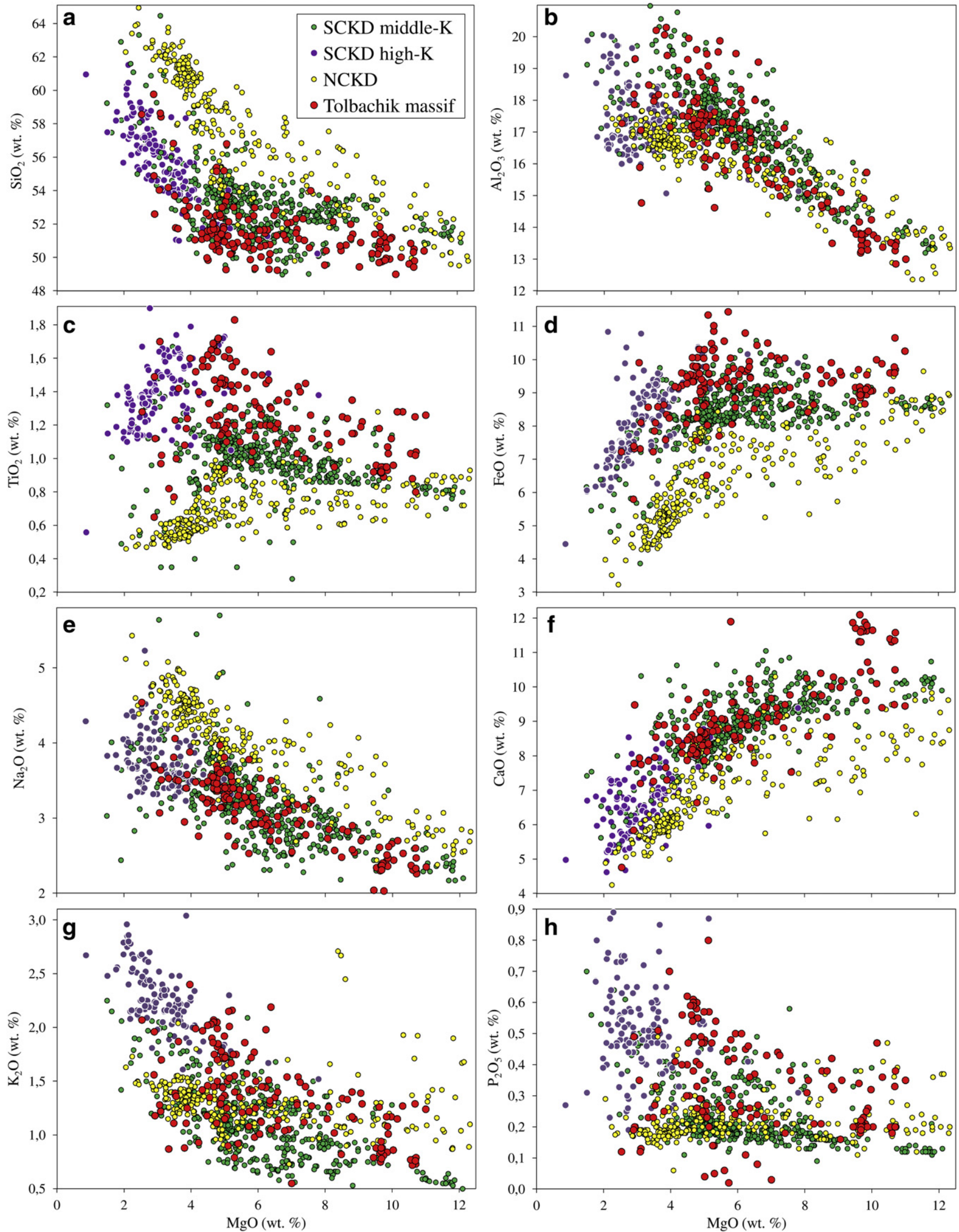

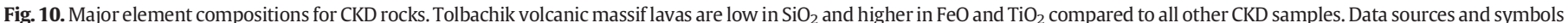
are the same as in Fig. 4. 
lavas appear at $1.7 \mathrm{ka}$ during age period III (1.4-1.7 ka) when all of the rock types were erupted but high-K trachybasalts still dominant. During this time some eruptions were producing a variety of compositionally different magmas. Essentially the same situation continued during age period IV (0.8-1.4 ka), when all lava types except type IV were erupted, and the relative volume of high-Mg rocks began to increase. From $0.8 \mathrm{ka}$ up to historical time only one high-Mg eruption is known, from Krasny cone; all other eruptions were dominated by high-K trachybasaltic lavas (type III). During historical time lavas of all four types have been erupted: all summit eruptions are high-K trachybasalts of type III, the rocks of 1941 eruption are high-Mg basalts of type I, and during the 1975-1976 eruption all four types were erupted, but lavas of types II and IV had relatively small volumes.

Thus, although the two main basaltic series, high-Mg basalts and high-K basalts, have been found within the zone of monogenetic scoria cones, the high-K basalts are volumetrically dominant during the Holocene. The two basaltic series have different major element concentrations with the largest variations in $\mathrm{MgO}$ and $\mathrm{Al}_{2} \mathrm{O}_{3}$. The $\mathrm{MgO} / \mathrm{Al}_{2} \mathrm{O}_{3}$ and $\mathrm{K}_{2} \mathrm{O} / \mathrm{Na}_{2} \mathrm{O}$ ratios of these two series form separate fields that are not overlapping and have different fractionation trends inside the fields. The compositions of the type II products remain close to high-Mg rocks, while the compositions of type IV erupted material remain close to those of the high-K basalts.

Based on these systematic differences it has been suggested that two basaltic primary melts exist below the fissure eruption zone of the monogenetic cones, which form two rocks series that are not genetically related. All chemical variations in the intermediate lavas were explained by the mixing of these two basaltic melts (Braitseva et al., 1984; Flerov et al., 1984).

\subsection{Trace elements and isotope geochemistry}

Trace element data for basalts from the zone of monogenetic cones as well as genetically linked Holocene summit eruptions of Plosky Tolbachik stratovolcano support previously mentioned petrogenetic relationships. Trace element distribution patterns in the Tolbachik lavas overlap the range of trace element patterns in all CKD samples (Fig. 5). High-Mg products of type I are rich in $\mathrm{Cr}, \mathrm{Ni}, \mathrm{Co}, \mathrm{V}$, less in $\mathrm{Zn}$ and $\mathrm{Sr}$ while the high-K trachybasalts are strongly enriched in $\mathrm{Rb}, \mathrm{Ba}$, $\mathrm{Li}, \mathrm{B}, \mathrm{Be}$, and in most incompatible trace elements (except $\mathrm{Sr}$ ) including HFSE (Zr, Nb, Ta, Hf), Y and REE (e.g., Petrov et al., 1979; Churikova et al., 2001). Additionally the high-Mg basalts have higher concentrations of $\mathrm{Pt}$ and higher $\mathrm{Pt} /(\mathrm{Pt}+\mathrm{Pd})$ ratios while high-K trachybasalts are enriched in $\mathrm{Au}, \mathrm{Ag}$ and $\mathrm{Ag} / \mathrm{Au}$ ratios (Anoshin et al., 1982, 1983). The two rocks series are also systematically different in trace element ratios: $\mathrm{La} / \mathrm{Yb}, \mathrm{Ce} / \mathrm{Y}$ and $\mathrm{V} / \mathrm{Ni}$ are higher and $\mathrm{Ni} / \mathrm{Co}$ is lower in high-K rocks compared to high-Mg basalts (Fig. 11). A Eu anomaly is absent in all studied samples (Flerov et al., 1984).

High variability in whole rock $\mathrm{Sr}$-isotopes and in $\delta^{18} \mathrm{O}$ from normal to high- $\delta^{18} \mathrm{O}$ in phenocrysts from rocks of the KGV together with studies of melt inclusions argue for the interaction of normal- $\delta^{18} \mathrm{O}$ melts from a peridotite mantle source with high- $\delta{ }^{18} \mathrm{O}$ sources like lithospheric mantle, lower crust or slab fluid flux (Dorendorf et al., 2000; Bindeman et al., 2004; Portnyagin et al., 2007a; Auer et al., 2009). The Sr, Nd, Pb and $\delta^{18} \mathrm{O}$ isotope data for high-Mg and high-K basalts from the Tolbachik zone of monogenetic cones are lower compared to the other CKD rocks (Fig. 12a); this limits the amount of sediment that could be incorporated in the mantle source region to less than one percent (Kersting, 1995; Turner et al., 1998; Churikova et al., 2001). The ranges in ${ }^{238} \mathrm{U} /{ }^{232} \mathrm{Th}$ ratios $(1.89-1.94)$ and ${ }^{230} \mathrm{Th} /{ }^{232} \mathrm{Th}$ ratios $(1.83-1.98)$ are relatively narrow for the Tolbachik lavas. The majority of samples are close to the equiline indicating that the time since $U / T h$ fractionation is generally 150 thousand years (Turner et al., 1998, 2001; Dosseto et al., 2003). ${ }^{187} \mathrm{Os} /{ }^{188} \mathrm{Os}$ and ${ }^{187} \mathrm{Re} /{ }^{188} \mathrm{Os}$ ratios also show rather similar values for both high-Mg and high-K samples: 0.175 and 0.147, 235 and 183,
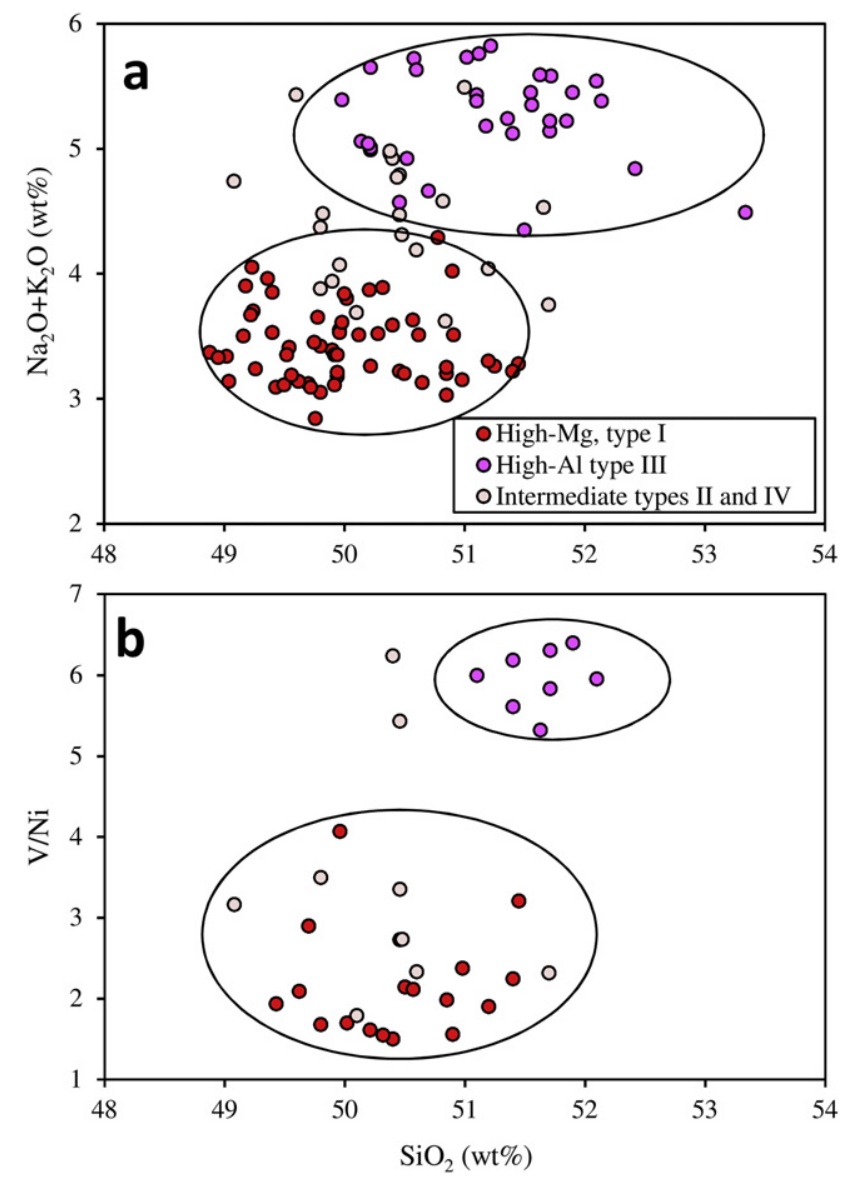

Fig. 11. Major and trace element compositions for the lavas of the Tolbachik monogenetic scoria cones (a) Weight percent $\mathrm{Na}_{2} \mathrm{O}+\mathrm{K}_{2} \mathrm{O}$ versus $\mathrm{SiO}_{2}$ (b) $\mathrm{Ni} / \mathrm{V}$ versus weight percent $\mathrm{SiO}_{2}$. Ovals show the fields of the high-Mg and high-Al lavas. Data from dataset of Portnyagin et al. (2007a).

respectively (Alves et al., 1999), which also is inconsistent with a significant role of sediments in the magma sources.

\subsection{Origin of the two parental magma series}

The origin of the two parental magma series is still under debate. On some binary trace element diagrams (e.g., Rb vs. Ba, Rb vs. Sr) high-K and high-Mg basalts form separate and non-overlapping fields just as for the major elements. Moreover, experimental data indicate that the high-Mg basalts crystallized at higher $\mathrm{CO}_{2}$ pressure and at nearly dry conditions while high-K basalts crystallized at low $\mathrm{CO}_{2}$ pressure but higher water contents, which is consistent with greater depths of crystallization for the phenocrysts in the high-Mg lavas (Table 3; Lukanin et al., 1980; Romanchev and Flerov, 1980; Flerov et al., 1980). However, recent melt inclusion studies from samples of high-Mg Tolbachik basalt from 1004 cone (Fig. 9) show $\mathrm{H}_{2} \mathrm{O}$ concentrations of $2.42 \mathrm{wt} . \%$ (Portnyagin et al., 2007b), which is much higher than previously reported. Based on large differences in all trace elements and their ratios, locations in different fields on major and trace element diagrams, and different fractionation trends inside two compositional fields coupled with different $\mathrm{P}-\mathrm{T}-\mathrm{H}_{2} \mathrm{O}-\mathrm{CO}_{2}$ conditions, Flerov et al. (1984) suggested that the two series derive from different mantle sources.

Sub-parallel trace element patterns and similar primitive $\mathrm{Sr}$ and $\mathrm{Nd}$ isotopic compositions are also consistent with the two series being derived from a similar mantle source. The most pronounced enrichment of high-K trachybasalts compared to high-Mg basalts was observed in fluid-mobile elements ( $\mathrm{K}, \mathrm{Rb}, \mathrm{P}, \mathrm{Ba}$ and $\mathrm{Pb}$ ). The high-K basalts are also enriched in $\delta^{18} \mathrm{O}$ and in $\mathrm{H}_{2} \mathrm{O}$ compared to high-Mg lavas (Pineau 

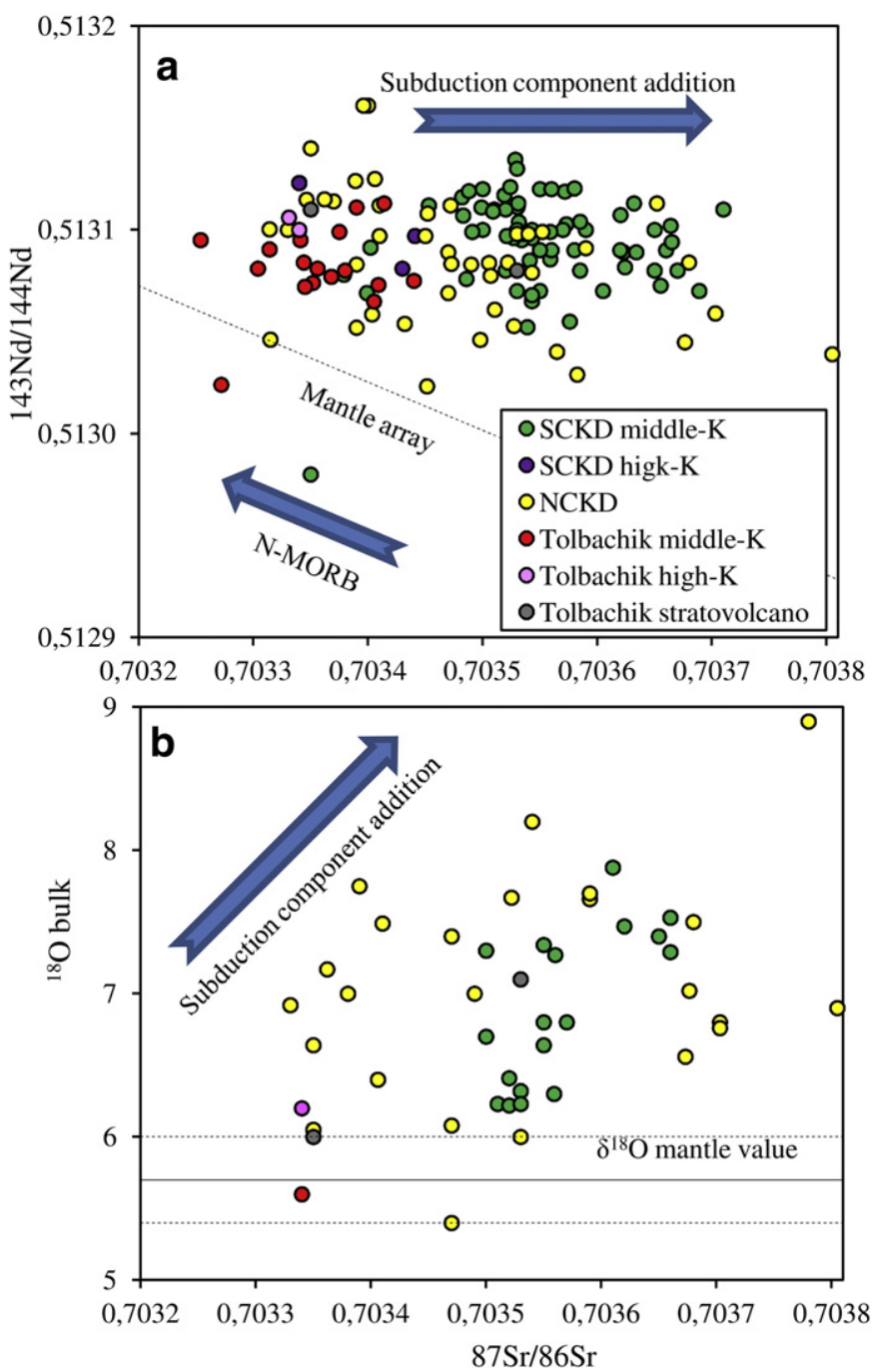

Fig. 12. Isotopic compositions for samples from the CKD. (a) ${ }^{143} \mathrm{Nd} /{ }^{144} \mathrm{Nd}$ versus ${ }^{87} \mathrm{Sr} /{ }^{86} \mathrm{Sr}$ (b) $\delta^{18} \mathrm{O}$ versus ${ }^{87} \mathrm{Sr} /{ }^{86} \mathrm{Sr}$. Data from the Tolbachik volcanic massif are divided into middle$\mathrm{K}$ (red circles) and high-K (pink circles) lavas. Other symbols are as in Fig. 4. The mantle array for Sr-Nd systematics is defined by MORB and OIB compositions after DePaolo and Wasserburg (1976) and McCulloch and Perfit (1981). The assumed mantle value of $\delta^{18} \mathrm{O}$ is from Taylor (1980). Data sources are from the datasets of Portnyagin et al. (2007a) and Almeev et al. (2013a).

et al., 1999; Portnyagin et al., 2007a). Based on these data Churikova et al. (2001, 2013) concluded that high-Mg and high-K melts could be produced from a similar mantle source that had experienced different degrees of depletion (less depleted for high-K trachybasalts) and different fluid enrichment (higher for high-K trachybasalts).

Almost no trace element and isotopic data exist for samples from the Tolbachik pedestal and stratovolcanoes, except one sample PT33-1/82, which was analyzed for trace elements, and $\mathrm{Sr}, \mathrm{Nd}, \mathrm{Pb}, \mathrm{U}-\mathrm{Th}-\mathrm{Pa}-\mathrm{Ra}$ and Re-Os isotopes (Alves et al., 1999; Pineau et al., 1999; Dosseto et al., 2003). But a new dataset of analyses from these regions are presented by Churikova et al. (2015).

\section{Volcano monitoring}

Although the volcanoes of the KGV are relatively remote, they have been monitored via the Kamchatka Volcano Observatory in Klyuchi settlement since its establishment on 1 September 1935 (Ivanov, 1983; Fig. 2). Much of the early work of the observatory scientists up through 1975-1976 was summarized by Ivanov (1983), who outlined the development of Russian volcanology and the importance to those studies of Kamchatka volcanoes. The earliest work involved making observations on eruptions of Klyuchevskoy volcano, which had already been recognized as one of the world's most active volcanoes. Within a decade after establishing the observatory at Klyuchi, a seismic station was added to it, followed by another seismic station at Kozyrevsk settlement, along with the completion of an aerial photographic survey of Kamchatka's volcanoes (Ivanov, 1983). The GTFE is a classic example of using seismicity to predict an impending eruption. More than a week prior to the onset at the Northern Breakthrough, a series of large (M 4-5) earthquakes were registered by regional seismometers (Tokarev, 1978; Fedotov and Markhinin, 1983). The epicenters were correlated to Tolbachik, and based on the new level of seismicity an eruption was predicted for the following week. The eruption onset occurred within the predicted window. This strong precursory earthquake activity before the 1975-1976 eruption is one of the reasons the 2012-2013 eruption onset was surprising: although the regional seismic network is now much better, the magnitudes of the earthquakes leading up to the eruption were much smaller and so were only recognized by retrospective analysis (Senyukov et al., 2015).

Because volcanoes in Kamchatka have potential for generating significant ash plumes that can be carried to the east and intersect well-traveled flight paths between North America and Eurasia; thus the Kamchatka Volcanic Eruption Response Team (KVERT) is constantly monitoring volcanic activity in the area using satellite imagery (http:// www.kscnet.ru/ivs/kvert/index_eng.php). As well, the Kamchatka Branch of the Russian Geophysical Survey maintains a monitoring network of seismological stations located within the KGV (http://www. emsd.ru; Senyukov et al., 2015), including five permanent stations within $20 \mathrm{~km}$ of Tolbachik and several permanent GPS stations. The 2012-2013 eruption was a milestone for monitoring efforts of Kamchatka eruptions that not only included analysis of seismic and deformation data, but also significant ground-based measurements of lava temperatures (e.g., Edwards et al., 2014, 2015), time-series measurements of lava and scoria compositions (Volynets et al., 2015), and extensive monitoring of activity via remote sensing of thermal bands (e.g., the Moderate Resolution Imaging Spectroradiometer or MODIS; Telling et al., 2015) as well as instruments that are sensitive to detection of $\mathrm{SO}_{2}$ (the Ozone Monitoring Instrument or OMI, the Ozone Mapping and Profiler Suite or OMPS, and the Atmospheric Infrared Sounder or AIRS; Telling et al., 2015).

\section{Summary}

The majority of the information on the geology and petrology of the Tolbachik volcanic massif was obtained as a direct result of the 19751976 Great Tolbachik Fissure Eruption (Fig. 11). However, these studies produced some controversial conclusions that should be addressed by future research.

\subsection{Geology}

The geological map of Tolbachik volcanic massif was compiled in 1970's by Ermakov and Vazheevskaya (1973). However the tectonic position of the southwestern part of the KGV is not clear. For example, the relationship between the Tolbachik pedestal and KGV basement is not fully understood. Furthermore, several volcanoes neighboring the Tolbachik massif on the east (Zimina, Gorny Zub) and south (Nikolka) are very poorly studied.

\subsection{Geochemistry}

A detailed petrological map has been created for the Tolbachik monogenetic lava field (Flerov et al., 1984; see also Fig. 9b). The 1975-1976 lavas have been well studied using high-precision, modern methods of geochemistry and isotope chemistry (e.g., Alves et al., 1999; Münker et al., 2004; Dosseto et al., 2003; Dosseto and Turner, 2014). Two genetically unrelated high-Mg and high-K rock series have 
been identified with the Tolbachik monogenetic cone zone (e.g., Flerov et al., 2015 and many others). Several factors have been suggested to explain the origin of these rock series: variable depletion of the mantle wedge; variable addition of subduction components (aqueous fluids/ supercritical liquids/slab melt); and, fractional crystallization within each series followed by mixing (e.g., Flerov et al., 1984; Churikova et al., 2001; Portnyagin and Manea, 2008). The mantle wedge below the Tolbachik massif appears to be hottest inside the CKD (about $1350{ }^{\circ} \mathrm{C}$ ) and the water content of melt inclusions from high-Mg Ol reach 2.42 wt.\% (Portnyagin et al., 2007b; Portnyagin and Manea, 2008). However, crystallization experiments and mineral compositions suggested for magma fractionation require much lower water contents in both rock series and large differences in crystallization pressures: 0.4-0.7 GPa for high-Mg melts and subsurface conditions for high-K lavas (Flerov et al., 1984).

At the same time other rocks and units of the Tolbachik volcanic massif are still poorly studied geochemically. Even some of the scoria cones and lava flows of the Holocene Tolbachik monogenetic lava field are geochemically not well characterized at present. As result it is impossible to reconstruct the complete history of the Tolbachik volcanic massif as its geotectonic regime changed and to evaluate the geochemical response to the changes.

\subsection{Geophysics}

The new 2012-2013 eruption at the Tolbachik monogenetic lava field shows that eruptions can start with very little notice. However, while the place and time of the 1975-1976 GTFE was predicted with great accuracy due to strong seismic activity (Tokarev, 1978), the 2012-2013 eruption was not forecast. Retrospective analysis of seismic and deformation data has identified precursory signals however (Kugaenko et al., 2015). We suggest that this potentially dangerous "corner" of the KGV should be closely monitored in the future. Although the KGV has been well investigated by geophysical methods, many questions exist about the deep structure of the plumbing systems below individual volcanoes and even individual eruptions. This problem can be solved by using new methods such as local earthquake tomography (Koulakov et al., 2011, 2013), passive seismic interferometry, high resolution surface wave tomography from ambient seismic noise (Shapiro et al., 2005), 4D ambient seismic noise imaging (Brenguier et al., 2008), seismic amplitude ratio analysis for imaging the dynamics of magma propagation (Taisne et al., 2011), and low-frequency microseismic sounding (Gorbatikov et al., 2013; Kugaenko et al., 2013). These kinds of studies may be very helpful to explain the variety of lava compositions erupted during the 1975-1976 and 2012-2013 eruptions.

\subsection{Geochronology}

The Holocene history of the Tolbachik monogenetic lava field was reconstructed in details using tephrochronology and radiocarbon dating (e.g., Braitseva et al., 1981, 1984; Fig. 9a). However, the Pleistocene history of the Tolbachik volcanic massif and surrounding volcanoes as well as the CKD structure is still unknown, which inhibits understanding of the relationships between the chemical composition of the volcanic rocks and changes in space and time related to large-scale tectonic processes.

Recent long-term international projects on Bezymianny and Klyuchevskoy volcanoes (PIRE project and Japanese-Russian project, respectively) provide valuable data for the two most active volcanoes in the KGV. These data permit analysis of magma generation, storage, transport, evolution and eruption above a tectonically complex triple plate junction. We hope that Tolbachik volcanic massif, with its extremely primitive and varied basaltic magmas and unusual style of Hawaiian type, rift-like structure for the subduction setting is the best candidate for future multidisciplinary studies.

\section{Acknowledgments}

We are very grateful to Gerhard Wörner, Alexander Belousov and an anonymous reviewer for their useful comments on an earlier version of the manuscript. This work was supported by grant $\S 13-05-92104$ from the Russian Foundation for Basic Research (RFBR) to Tatiana Churikova. The initial stages of CKD research were supported by RFBR, INTAS, DFG and Volkswagen foundations to Tatiana Churikova and Gerhard Wörner. Discussions with I.V. Melekestsev, G.B. Flerov, Yu. A. Kugaenko, L.P. Vergasova and O. Bergal-Kuvikas helped us to improve this manuscript.

\section{Appendix A. Supplementary data}

Supplementary data associated with this article can be found in the online version at http://dx.doi.org/10.1016/j.jvolgeores.2015.10.016. These data include the Google map of the most important areas described in this article.

\section{References}

Alexeiev, D.V., Gaedicke, C., Tsukanov, N.V., Freitag, R., 2006. Collision of the Kronotskiy arc at the NE Eurasia margin and structural evolution of the Kamchatka-Aleutian junction. Int. J. Earth Sci. (Geol. Rundsch.) 95, 977-993.

Almeev, R.R., Kimura, J.I., Ariskin, A.A., Ozerov, A.Yu., 2013a. Decoding crystal fractionation in calc-alkaline magmas from the Bezymianny Volcano (Kamchatka, Russia) using mineral and bulk rock compositions. J. Volcanol. Geotherm. Res. 263, 141-171.

Almeev, R.R., Ariskin, A.A., Kimura, J.I., Barmina, G.S., 2013b. The role of polybaric crystallization in genesis of andesitic magmas: phase equilibria simulations of the Bezymianny volcanic subseries. J. Volcanol. Geotherm. Res. 263, 182-192.

Alves, S., Schiano, P., Allegre, C.J., 1999. Rhenium-osmium isotopic investigation of Java subduction zone lavas. Earth Planet. Sci. Lett. 168, 65-77.

Anoshin, G.N., Volynets, O.N., Flerov, G.B., 1982. The geochemistry of gold and silver in basalts of the Grate fissure Tolbachik Eruption 1975-1976. Doclady AS USSR 264 (1) pp. 195-197.

Anoshin, G.N., Volynets, O.N., Flerov, G.B., 1983. First data on distribution of platinum in modern basalts of Kamchatka. Doclady AS USSR 268 (4) pp. 967-969.

Ariskin, A.A., 1999. Phase equilibria modeling in igneous petrology: use of COMAGMAT model for simulating fractionation of ferro-basaltic magmas and the genesis of high-alumina basalt. J. Volcanol. Geotherm. Res. 90, 115-162.

Auer, S., Bindeman, I., Wallace, P., Ponomareva, V., Portnyagin, M., 2009. The origin of hydrous, high-d180 voluminous volcanism: diverse oxygen isotope values and high magmatic water contents within the volcanic record of Klyuchevskoy volcano, Kamchatka, Russia. Contrib. Mineral. Petrol. 157, 209-230.

Balesta, S.T., 1991. Earth crust structure and magma chambers of the areas of present Kamchatka volcanism. In: Fedotov, S.A., Masurenkov, Y.P. (Eds.), Active Volcanoes of Kamchatka. Nauka, Moscow, pp. 36-45.

Bazanova, L.I., Pevzner, M.M., 2001. Khangar: one more active volcano in Kamchatka. Trans. Russ. Acad. Sci. Earth Sci. 377A, 307-310.

Belousov, A.B., 1995. The Shiveluch volcanic eruption of 12 November 1964-explosive eruption provoked by failure of the edifice. J. Volcanol. Geotherm. Res. 66, 357-365.

Belousov, A., 1996. Pyroclastic deposits of March 30, 1956 directed blast at Bezymianny volcano. Bull. Volcanol. 57, 649-662.

Bindeman, I.N., Ponomareva, V.V., Bailey, J.C., Valley, J.W., 2004. Volcanic arc of Kamchatka: a province with high-d ${ }^{18} \mathrm{O}$ magma sources and large-scale ${ }^{18} \mathrm{O} /{ }^{16} \mathrm{O}$ depletion of the upper crust. Geochim. Cosmochim. Acta 68, 841-865.

Braitseva, O.A., Melekestsev, I.V., Flerov, G.B., Ponomareva, V.V., Litasova, S.N., Sulerzhitsky, L.D., 1981. Tephrochronological and geochronological of the Tolbachik regional zone of cinder cones. Volcanol. Seismol. 3, 14-28.

Braitseva, O.A., Melekestsev, I.V., Flerov, G.B., Ponomareva, V.V., Sulerzhitsky, L.D., Litasova, S.N., 1984. Holocene volcanism of the Tolbachik regional zone of cinder cones. In: Fedotov, S.A. (Ed.), Great Tolbachik Fissure Eruption, Kamchatka, 19751976. Nauka, Moscow, pp. 177-209 (In Russian).

Braitseva, O.A., Sulerzhitsky, L.D., Litasova, S.N., Grebzdy, E.I., 1988. Radiocarbon dating of soils and pyroclastic deposits in Kliuchevskoi group of volcanoes. Volcanol. Seismol. 6, 317-325.

Braitseva, O.A., Melekestsev, I.V., Bogoyavlenskaya, G.E., Maksimov, A.P., 1991. Bezymyannyi: eruptive history and dynamics. Volcanol. Seismol. 12, 165-194.

Braitseva, O.A., Sulerzhitsky, L.D., Litasova, S.N., Melekestsev, I.V., Ponomareva, V.V., 1993. Radiocarbon dating and tephrochronology in Kamchatka. Radiocarbon 35 (3), 463-476.

Braitseva, O.A., Melekestsev, I.V., Ponomareva, V.V., Sulerzhitsky, L.D., 1995. The ages of calderas, large explosive craters and active volcanoes in the Kuril-Kamchatka region, Russia. Bull. Volcanol. 57 (6), 383-402.

Braitseva, O.A., Ponomareva, V.V., Sulerzhitsky, L.D., Melekestsev, I.V., Bailey, J., 1997 Holocene key-marker tephra layers in Kamchatka, Russia. Quat. Res. 47, 125-139.

Brenguier, F., Shapiro, N.M., Campillo, M., Ferrazzini, V., Duputel, Z., Coutant, O., Nercessian, A., 2008. Towards forecasting volcanic eruptions using seismic noise. Nat. Geosci. 1, 126-130. http://dx.doi.org/10.1038/ngeo104.

Bryant, J.A., Yogodzinski, G.M., Churikova, T.G., 2007. Melt-mantle interactions beneath the Kamchatka arc: evidence from ultramafic xenoliths from Shiveluch volcano. 
Geochem. Geophys. Geosyst. 8 (4), 1-24, 004007. http://dx.doi.org/10.1029/ 2006GC001443.

Bryant, J.A., Yogodzinski, G.M., Churikova, T.G., 2011. High Mg\# andesites of the Shisheisky complex, Northern Kamchatka: implications for Primitive Magmatism in Subduction Systems. Contrib. Mineral. Petrol. 161, 791-810. http://dx.doi.org/10. 1007/s00410-010-0565-4

Calkins, J.A., 2004. ${ }^{40} \mathrm{Ar} /{ }^{39} \mathrm{Ar}$ geochronology of Khapitsa plateau and Studyonaya river basalts and basaltic andesites in Central Kamchatka Depression, Kamchatka, Russia. In: Gordeev, E.I. (Ed.), Linkages Among Tectonics, Seismicity, Magma Genesis, an Eruption in Volcanic ArcsIV International Biennial Workshop on Subduction Processes Emphasizing the Japan-Kurile-Kamchatka-Aleutian Arcs. Institute of Volcanology and Seismology FEB RAS, Petropavlovsk-Kamchatsky, pp. 53-54

Churikova, T.G., 1993. Geochemistry and Modeling of the Magmatic Processes of the Klyuchevskaya Group of Volcanoes (PhD thesis) Lomonosov Moscow State University, Moscow (in Russian).

Churikova, T., Dorendorf, F., Wörner, G., 2001. Sources and fluids in the mantle wedge below Kamchatka, evidence from across-arc geochemical variation. J. Petrol. 42 1567-1593.

Churikova, T., Wörner, G., Mironov, N., Kronz, A., 2007. Volatile (S, Cl and F) and fluid mobile trace element compositions in melt inclusions: implications for variable fluid sources across the Kamchatka arc. Contrib. Mineral. Petrol. 154, 217-239.

Churikova, T.G., Gordeychik, B.N., Wörner, G., Ivanov, B.V., 2013. Interrelationship between Kamen Volcano and Klyuchevskaya group of volcanoes (Kamchatka). J. Volcanol. Geotherm. Res. 263, 3-21.

Churikova, T., Gordeychik, B., Iwamori, H., Nakamura, H., Nishizawa, T., Haraguchi, S. Yasukawa, K., Ishizuka, O., 2014. Petrology and geochemistry of the Tolbachik stratovolcano. 8nd International Seismic-Volcanic Workshop on North-Japanese, KurileKamchatkan, and Aleutian-Alaskan Subduction Processes, Hokkaido, Japan (http:// hkdrcep.sci.hokudai.ac.jp/map/jkasp2014/pdf/R50.pdf).

Churikova, T.G., Gordeychik, B.N., Iwamori, H., Nakamura, H., Ishizuka, O., Nishizawa, T. Haraguchi, S., Miyazaki, T., Vaglarov, B.S., 2015. Petrological and geochemical evolution of the Tolbachik volcanic massif, Kamchatka, Russia. J. Volcanol. Geotherm. Res. 307, 156-181.

Davaille, A., Lees, J.M., 2004. Thermal modeling of subducted plates: tear and hotspot at the Kamchatka corner. Earth Planet. Sci. Lett. 226, 293-304.

DeMets, C., Gordon, R., Argus, D., Stein, S., 1990. Current plate motions. Geophys. J. Int 101, 425-478.

DePaolo, D.J., Wasserburg, G.J., 1976. Inferences about magma sources and mantle structure from variations of $143 \mathrm{Nd} / 144 \mathrm{Nd}$. Geophys. Res. Lett. 3, 743-746.

Dorendorf, F., Wiechert, U., Wörner, G., 2000. Hydrated sub-arc mantle: a source for the Kluchevskoy volcano, Kamchatka/Russia. Earth Planet. Sci. Lett. 175, 69-86.

Dosseto, A., Turner, S., 2014. Reappraisal of uranium-series isotope data in Kamchatka lavas: implications for continental arc magma genesis. Geochem. Soc. Spec. Publ. $385,103-116$.

Dosseto, A., Bourdon, B., Joron, J.L., Dupre, B., 2003. U-Th-Pa-Ra study of the Kamchatka arc: new constraints on the genesis of arc lavas. Geochim. Cosmochim. Acta 67, 2857-2877.

Dvigalo, V.N., Chirkov, A.M., Fedotov, S.A., 1984. New summit caldera of Ploskiy Tolbachik volcano. In: Fedotov, S.A. (Ed.), Great Tolbachik Fissure Eruption, Kamchatka, 19751976. Nauka, Moscow, pp. 75-84 (In Russian).

Dvigalo, V.N., Fedotov, S.A., Chirkov, A.M., 1991. Plosky Tolbachik. In: Fedotov, S.A. Masurenkov, Yu.P. (Eds.), Active Volcanoes of Kamchatka 1. Nauka, Moskow, pp. 200-211.

Edwards, B.R., Belousov, A., Belousova, M., 2014. Propagation style controls lava-snow interactions. Nat. Commun. 5, 1-5. http://dx.doi.org/10.1038/ncomms6666.

Edwards, B.R., Belousov, A., Belousova, M., Melnikov, D., 2015. Observations on lava, snowpack and their interactions during the 2012-13 Tolbachik eruption, Klyuchevskoy Group, Kamchatka, Russia. J. Volcanol. Geotherm. Res. 307, 107-119.

Eichelberger, J., Gordeev, E., Kasahara, M., Izbekov, P., Lees, J. (Eds.), 2007. Volcanism and subduction: the Kamchatka regionGeophysical Monograph Series vol. 172. American Geophysical Union, Washington, DC (369 pp.)

Erlich, E.N. (Ed.), 1966. Petrochemistry of the Kuril-Kamchatka volcanic province. Nauka, Moscow (278 pp. (in Russian)).

Ermakov, V.A., 1977. Formation dismemberment of the Quaternary volcanic rocks. Nedra, Moscow (223 pp. (in Russian))

Ermakov, V.A., Vazheevskaya, A.A., 1973. Ostry and Plosky Tolbachik volcanoes. Bull. Volcanol. Stations 49, 43-53 (in Russian).

Fedotov, S.A., 1984. The 1975-1976 Large Tolbachik Fissure Eruption in Kamchatka. Sceince, Moscow (637 pp.)

Fedotov, S.A., Markhinin, Ye.K. (Eds.), 1983. The Great Tolbachik Fissure Eruption: Geologica and Geophysical Data 1975-1976. Cambridge University Press, Cambridge (354 pp.).

Fedotov, S.A., Masurenkov, Yu.P. (Eds.), 1991. Active volcanoes of Kamchatka vol. 1 (302 pp., Nauka, Moscow)

Fedotov, S.A., Balesta, S.T., Dvigalo, V.N., Razina, A.A., Flerov, G.B., Chirkov, A.M., 1991. New Tolbachik Volcanoes. In: Fedotov, S.A., Masurenkov, Yu.P. (Eds.), Active Volcanoes of Kamchatka 1. Nauka, Moscow, pp. 214-281.

Fedotov, S.A., Zharinov, N.A., Gontovaya, L.I., 2010. The magmatic system of the Klyuchevskaya group of volcanoes inferred from data on its eruptions, earthquakes, deformation, and deep structure. J. Volcanol. Seismol. 4 (1), 1-33.

Fedotov, S.A., Utkin, I.S., Utkina, L.I., 2011. The peripheral magma chamber of Ploskii Tolbachik, a Kamchatka basaltic volcano: activity, location and depth, dimensions, and their changes based on magma discharge observations. J. Volcanol. Seismol. 5 (6), 369-385

Flerov, G.B., Melekestsev, I.V., 2013. Eruption 2012-2013 as a result of the ongoing activity of Tolbachik regional zone of cinder cones (Klyuchevskaya group of volcanoes, Kamchatka). In: Gordeev, E.I. (Ed.), Volcanism and associated processes. Regional scientific conference dedicated to the Day of volcanologist. March 29-30, 2013. Institute of Volcanology and Seismology FEB RAS, Petropavlovsk-Kamchatsky, pp. 139-144 ((In Russian). http://www.kscnet.ru/ivs/publication/volc_day/2013/ art20.pdf).

Flerov, G.B., Ovsyannikov, A.A., 1991. Ushkovsky volcano. In: Fedotov, S.A., Masurenkov, Yu.P. (Eds.), Active Volcanoes of Kamchatka 1. Nauka, Moskow, pp. 164-165.

Flerov, G.B., Sobolev, A.V., Koloskov, A.V., 1980. Pyroxenes, olivines and spinelli in the rocks of Grate fissure Tolbachik eruption. J. Volcanol. Seismol. 3, 3-15.

Flerov, G.B., Andreev, V.N., Budnikov, V.A., Tsyurupa, A.I., 1984. Petrology of the eruption products. In: Fedotov, S.A. (Ed.), Great Tolbachik Fissure Eruption, Kamchatka, 19751976. Nauka, Moscow, pp. 223-284 (In Russian).

Flerov, G.B., Ananjev, V.V., Ponomarev, G.P., 2015. Petrogenesis of the rocks from Ostry and Plosky Tolbachiks and the relationship of the volcanic manifestations of basaltic and trachibasaltic magmas at the Tolbachinsky Dol area (Kamchatka). J. Volcanol. Seismol. 9 (3), 162-181.

Geist, E.L., Scholl, D.W., 1994. Large-scale deformation related to the collision of the Aleutian Arc with Kamchatka. Tectonics 13, 538-560.

Gilichinsky, M., Melnikov, D., Melekestsev, I., Zaretskaya, N., Inbar, M., 2010. Morphometric measurements of cinder cones from digital elevation models of Tolbachik volcanic field, central Kamchatka. 36 (4), 287-300.

Gorbach, N.V., Portnyagin, M.V., 2011. Geology and petrology of the lava complex of Young Shiveluch volcano, Kamchatka. Petrology 19 (2), 140-172.

Gorbach, N., Portnyagin, M., Tembrel, I., 2013. Volcanic structure and composition of Old Shiveluch volcano, Kamchatka. J. Volcanol. Geotherm. Res. 263, 193-208.

Gorbatikov, A.V., Montesinos, F.G., Arnoso, J., Stepanova, M.Yu., Benavent, M., Tsukanov, A.A., 2013. New features in the subsurface structure model of El Hierro Island (Canaries) from low-frequency microseismic sounding. An insight into the 2011 seismo-volcanic crisis. J. Surv. Geophys. 34 (4), 463-489. http://dx.doi.org/10.1007/ s10712-013-9240-4

Gorbatov, A., Kostoglodov, V., Suarez, G., Gordeev, E., 1997. Seismicity and structure of the Kamchatka subduction zone. J. Geophys. Res. 102 (B8), 17833-17898.

Gordeev, E.I., Girina, O.A., 2014. Volcanoes and their hazard to aviation, 2014. Her. Russ. Acad. Sci. 84 (1), 1-8.

Gorelchik, V.I., Shirokov, V.A., Firstov, P.P., Chubarova, O.S., 1997. Shiveluch Volcano; seismicity, deep structure and forecasting eruptions (Kamchatka). J. Volcanol. Geotherm. Res. 78, 121-137.

Gorelchik, V.I., Garbuzova, V.T., Storcheus, A.V., 2004. Deep_Seated Volcanic Processes beneath Klyuchevskoi Volcano from Seismological Data. Vulkanol. Seismol. 6, 21-34.

Grapenthin, R. Freymueller, J.T., Serovetnikov, S.S., 2013. Surface deformation of Bezymianny Volcano, Kamchatka, recorded by GPS: The eruptions from 2005-2010 and long-term, long-wavelength subsidence. J. Volcanol. Geotherm. Res. 263, 58-74. http://dx.doi.org/10.1016/j.jvolgeores.2012.11.012.

Grishin, S.Yu., Shlyakhov, S.A., 2009. Vegetation and soils of the Tolbachik area (Kamchatka). Vestnik KRAUNC Earth Sci. Ser. 2 (14), 130-142 (in Russian).

Hochstaedter, A.G., Kepezhinskas, P., Defant, M., Drummond, M., Koloskov, A., 1996. Insights into the volcanic arc mantle wedge from magnesian lavas from the Kamchatka arc. J. Geophys. Res. Solid Earth 101, 697-712.

Hofmann, A.W., 1988. Chemical differentiation of the Earth; the relationship between mantle, continental crust, and oceanic crust. In: Welin, E. (Ed.), Isotope Geochemistry; the Crafoord SymposiumEarth and Planetary Science Letters. Elsevier, Amsterdam, pp. 297-314.

Ionov, D.A., Bénard, A., Plechov, P.Yu., Shcherbakov, V.D., 2013. Along-arc variations in lithospheric mantle compositions in Kamchatka, Russia: First trace element data on mantle xenoliths from the Klyuchevskoy Group volcanoes. J. Volcanol. Geotherm. Res. 263, 122-131.

Ishikawa, T., Tera, F., Nakazawa, T., 2001. Boron isotope and trace element systematics of the three volcanic zones in the Kamchatka arc. Geochim. Cosmochim. Acta 65, $4523-4537$.

Ivanov, 1983. The Kamchatka volcano logical station and its part in the development of Soviet volcanology. In: Fedotov, S.A., Markhinin, Ye.K. (Eds.), The Great Tolbachik Fissure Eruption: Geological and Geophysical Data 1975-1976. Cambridge University Press, Cambridge, pp. 1-8.

Ivanov, B.V., 2008. Andesites of Kamchatka. Nauka, Moscow (365 pp. (in Russian))

Iwasaki, T., Levin, V., Nikulin, A., Iidaka, T., 2013. Constraints on the Moho in Japan and Kamchatka. Tectonophysics 609, 184-201. http://dx.doi.org/10.1016/j.tecto.2012.11. 023

Kayzar, T.M., Nelson, B.K., Bachmann, O., Bauer, A.M., Izbekov, P.E., 2014. Deciphering petrogenic processes using $\mathrm{Pb}$ isotope ratios from time-series samples at Bezymianny and Klyuchevskoy volcanoes, Central Kamchatka Depression. Contrib. Mineral. Petrol. 168, 1067.

Kepezhinskas, P., McDermott, F., Defant, M.J., Hochstaedter, A., Drummond, M.S., Hawkesworth, C.J., Koloskov, A., Maury, R.C., Bellon, H., 1997. Trace element and $\mathrm{Sr}-\mathrm{Nd}-\mathrm{Pb}$ isotopic constraints on a three-component model of Kamchatka Arc petrogenesis. Geochim. Cosmochim. Acta 61, 577-600.

Kersting, A.B., 1995. Pb isotope ratios of North Pacific sedimennts, sites 881, 883, and 884: implications for sediment recycling in the Kamchatkan Arc. Proc. ODP Sci. Results $145,383-388$.

Kersting A.B., Arculus, RJ. 1994. Klyuchevskoy volcano, Kamchatka, Russia: the role of high-fluxed, recharged, tapped and fractionated magma chamber(s) in the genesis of high- $\mathrm{Al}_{2} \mathrm{O}_{3}$ basalt from high-MgO basalt. J. Petrol. 35, 1-42.

Kersting, A.B., Arculus, R.J., 1995. Pb isotope composition of Klyuchevskoy volcano, Kamchatka and North Pacific sediments: implications for magma genesis and crustal recycling in the Kamchatkan arc. Earth Planet. Sci. Lett. 136, 133-148.

Kessel, R., Schmidt, M.W., Ulmer, P., Pettke, T., 2005. Trace element signature of subduction-zone fluids, melts and supercritical liquids at $120-180 \mathrm{~km}$ depth. Nature 437, 724-727. http://dx.doi.org/10.1038/nature03971. 
Khrenov, A.P., Dvigalo, V.N., Kirsanov, I.T., Fedotov, S.A., Gorelchik, V.I., Zharinov, N.A 1991. Klyuchevskoy volcano. In: Fedotov, S.A., Masurenkov, Yu.P. (Eds.), Active Volcanoes of Kamchatka 1. Nauka, Moscow, pp. 146-153.

Khubunaya, S.A., Sobolev, A.V., 1998. Primary melts of calc-alkaline magnesian basalts from the Klyuchevskoi volcano, Kamchatka. Dokl. Earth Sci. 360 (4), 537-539.

Khubunaya, S.A., Bogoyavlenskiy, S.O., Novgorodtseva, T.Y., Okrugina, A.I., 1994. The mineralogy of the Klyuchevskoi magnesian basalts depicting the fractionation in the magma chamber. Volkanol. Seismol. 15 (3), 315-338 (in Russian).

Khubunaya, S.A., Gontovaya, L.I., Sobolev, A.V., Nizkous, I.V., 2007. Magma chambers beneath the Klyuchevskoy volcanic group (Kamchatka). J. Volcanol. Seismol. 2, 98-118.

Kirsanov, I.T., Ponomarev, G.P., 1974. The eruption of Posky Tolbachik volcano and some of the features of its products. Bull. Volcanol. Stations Moscow 50, 53-63 (Moscow, (in Russian)).

Koloskov, A.V., 1999. Ultramafic inclusions and volcanics as self-regulating geological system. Nauchnij Mir, Moscow (223 pp.).

Konradi, S.A., 1925. Report on the work of the southern subdivision of Kamchatka expedition. Bull. of the national Russian geographical society v. 7, n. 1.

Konstantinovskaia, E.A., 2000. Geodynamics of an Early Eocene arc continental collision reconstructed from the Kamchatka Orogenic Belt, NE Russia. Tectonophysics 325, 87-105.

Konstantinovskaia, E.A., 2001. Arc-continent collision and subduction reversal in the Cenozoic evolution of the Northwest Pacific: an example from Kamchatka (NE Russia). Tectonophysics 333, 75-94

Koulakov, I., Gordeev, E.I., Dobretsov, N.L., Vernikovsky, V.A., Senyukov, S., Jakovlev, A., 2011. Feeding volcanoes of the Kluchevskoy group from the results of local earthquake tomography. Geophys. Res. Lett. 38, L09305. http://dx.doi.org/10.1029/ 2011 GL046957.

Koulakov, I., Gordeev, E.I., Dobretsov, N.L., Vernikovsky, V.A., Senyukov, S., Jakovlev, A., Jaxybulatov, K., 2013. Rapid changes in magma storage beneath the Klyuchevskoy group of volcanoes inferred from time-dependent seismic tomography. J. Volcanol. Geotherm. Res. 263, 75-91. http://dx.doi.org/10.1016/j.jvolgeores.2012.10.014.

Krasheninnikov, S.P., 1755. Opisanie Zemli Kamchatki (The description of Kamchatka) vol. 1, 2. Imperial Academy of Sciences, St Petersburg.

Kudo, A.M., Weill, D., 1970. An igneous plagioclase thermometer. Contrib. Mineral. Petrol. 25, 52-65.

Kugaenko, Yu., Titkov, N., Saltykov, V., 2015. Constraints on unrest in the Tolbachik volcanic zone in Kamchatka prior the 2012-13 flank fissure eruption of Plosky Tolbachik volcano fromlocal seismicity and GPS data. J. Volcanol. Geotherm. Res. 307, 38-46.

Kugaenko, Yu.A., Saltykov, V.A., Gorbatikov, A.V., Stepanova, M.Yu., 2013. Deep structure of the North Vent Area, Great Tolbachik Fissure Eruption of 1975-1976, Kamchatka: evidence from low frequency microseismic sounding. J. Volcanol. Seismol. 7 (5), 313-327.

Kulakov, V.S., 1936. Hawaiian type of volcanoes at Kamchatka. Priroda 10, 17-22 (in Russian).

Lander, A.V., Shapiro, M.N., 2007. The origin of the modern Kamchatka subduction zone. In: Eichelberger, J., Gordeev, E., Kasahara, M., Izbekov, P., Lees, J. (Eds.), Volcanism and tectonics of the Kamchatka peninsula and adjacent arcs. Geophys Monogr Ser 172, pp. 57-64.

Le Maitre, R.W., 1989. A classification of igneous rocks and glossary of terms. Recommendations of the IUGS commission on the systematics of igneous rocks. Blackwell, Oxford (256 pp.).

Levin, V., Shapiro, N., Park, J., Ritzwoller, M., 2002. Seismic evidence for catastrophic slab loss beneath Kamchatka. Nature 418, 763-767.

Levin, V., Droznina, S., Gavrilenko, M., Carr, M.J., Senyukov, S., 2014. Seismically active subcrustal magma source of the Klyuchevskoy volcano in Kamchatka, Russia. Geology 42 (11), 983-986. http://dx.doi.org/10.1130/G35972.1.

Lukanin, O.A., Kadik, A.A., Biggar, G.M., Fedotov, S.A., 1980. Physico-chemical conditions of crystallization of the basalts of Grate fissure Tolbachik eruption 1975-1976. Volcanol. Seismol. 3, 16-50.

Markhinin, E.K., 1964. Crater of Plosky Tolbachik volcano 6-8th of September 1962. Bull. Kamch. Volcanol. Stations 37, 41-45.

McCulloch, M.T., Perfit, M.R., 1981. ${ }^{143} \mathrm{Nd} /{ }^{144} \mathrm{Nd}, 87 \mathrm{Sr} / 86 \mathrm{Sr}$ and trace element constraints on the petrogenesis of Aleutian Island arc magmas. Earth Planet. Sci. Lett. 56, 167-179.

Melekestsev, I.V., 1980. Volcanism and Relief Formation. Nauka, Moscow (212 pp. (in Russian)).

Melekestsev, I.V., 2005. Mt. Sredny (Kliuchevskoi volcanic group, Kamchatka) is a gigantic allochthon rather than a separate volcano. Volcanol. Seismol. 3, 9-14 (In Russian).

Melekestsev, I.V., Braitseva, O.A., 1988. Gigantic rockslide avalanches on volcanoes. Volcanol. Seismol. 6, 495-508

Melekestsev, I.V., Kraevaya, T.C., Braitseva, O.A., 1970. Relief and deposits of young volcanic regions of Kamchatka. Nauka, Moscow (104 pp. (in Russian)).

Melekestsev, I.V., Braitseva, O.A., Sulerzhitsky, L.D., Kozhemyaka, N.N., Ogorodov, N.V., Egorova, I.A., Lupikina, E.G., 1971. The age of volcanoes of the Kurile-Kamchatka volcanic region. Volcanism and the Deep Interior of the Earth. Nauka, Moscow, pp. 68-75 (in Russian).

Melekestsev, I.V., Braitseva, O.A., Erlich, E.N., Kozhemyaka, N.N., 1974. Volcanic mountains and plains. In: Luchitsky, I.V. (Ed.), Kamchatka, Kurile and Commander Islands. Nauka, Moscow, pp. 162-234 (in Russian).

Melekestsev, I.V., Khrenov, A.P., Kozhemyaka, N.N., 1991. Tectonoc position and general description of volcanoes of northern group and Sredinny Range. In: Fedotov, S.A., Masurenkov, Yu.P. (Eds.), Active Volcanoes of Kamchatka 1. Nauka, Moskow, pp. 74-81.

Menyailov, A.A., 1953. The state of Tolbachik volcano in 1946-1948. Bull. Kamch. Volcanol. Stations 17, 41-45.

Mironov, N.L., Portnyagin, M.V., 2011. $\mathrm{H}_{2} \mathrm{O}$ and $\mathrm{CO}_{2}$ in parental magmas of Kliuchevskoi volcano inferred from study of melt and fluid inclusions in olivine. Russ. Geol. Geophys. 52, 1353-1367.
Mironov, N.L., Portnyagin, M.V., Pletchov, P.Yu., Khubunaya, S.A., 2001. Final stages of magma evolution in Klyuchevskoy volcano, Kamchatka: evidence from melt inclusions in minerals of high-alumina basalts. Petrology 9, 46-62.

Miyashiro, A., 1974. Volcanic rock series in island arcs and active continental margins. Am. J. Sci. 274, 321-355.

Münker, C., Wörner, G., Yogodzinski, G.M., Churikova, T., 2004. Behaviour of high field strength elements in subduction zones: constraints from Kamchatka-Aleutian arc lavas. Earth Planet. Sci. Lett. 224, 275-293.

Muravyev, Ya.D., Ashikhmanova, N.A., Ovsyannikov, A.A., Filosofova, T.M., 2002. The experience of aerosols studying from the crater glacier of the Plosky Tolbachik volcano (Kamchatka). Vulkanol. Seismol. 6, 29-35 (In Russian).

Naboko, S.I., Glavatskikh, S.F., 1983. Post-eruptive metasomatosis and ore formation. Nauka, Moscow (165 pp.).

Nishizawa, T., Nakamura, H., Churikova, T., Gordeychik, B., Ishizuka, O., Iwamori, H., 2014. Petrological and chronological study of primitive high-Mg andesite from monogenetic volcanoes in the forearc region of northern Kamchatka Peninsula. 8nd International Seismic-Volcanic Workshop on North-Japanese, Kurile-Kamchatkan, and AleutianAlaskan Subduction Processes, Hokkaido, Japan (http://hkdrcep.sci.hokudai.ac.jp/ map/jkasp2014/pdf/J32.pdf).

Ovsyannikov, A.A., Khrenov, A.P., Muraviev, Ya.D., 1985. Present fumarolic activity on Dalny Plosky volcano. Volcanol. Seismol. 5, 80-97 (In Russian).

Ozerov, A.Y., 2000. The evolution of high-alumina basalts of the Klyuchevskoy volcano, Kamchatka, Russia, based on microprobe analyses of mineral inclusions. J. Volcanol. Geotherm. Res. 95, 65-79.

Ozerov, A.Yu., Ariskin, A.A., Kyle, Ph., Bogoyavlenskaya, G.E., Karpenko, S.F., 1997. Petrological-geochemical model for genetic relationships between basaltic and andesitic magmatism of Klyuchevskoi and Bezymyannyi volcanoes, Kamchatka. Petrology 5, 550-569.

Park, J., Levin, V., Brandon, M., Lees, J., Peyton, V., Gordeev, E., Ozerov, A., 2002. A dangling slab, amplified arc volcanism, mantle flow and seismic anisotropy in the Kamchatka plate corner. In: Stein, S., Freymueller, J.T. (Eds.), Plate boundary zones. AGU Geodynamics Series 30, pp. 295-324.

Petrov, L.L., Volynets, O.N., Flerov, G.B., Andreev, V.N., Andreev, V.I., Budnikov, V.A., 1979 Distribution of flurine, boron, berillium, and $\mathrm{H}_{2} \mathrm{O}$ in rocks of Tolbachik eruption. Volcanol. Seismol. 3, 18-29.

Pevzner, M.M., 2006. Holocene volcanism of the Northern Kamchatka: space-temporal patterns. Trans. (Doklady) Russ. Acad. Sci. Earth Sci. Section 409A (6), 884-887.

Pevzner, M.M., Tolstykh, M.L., Babanskii, A.D., Leer, P., Volynets, A.O., 2014. Fierst data on isotope age and composition of the source melts of the rocks of the initial stage of activity of the Shiveluch volcanic massif, Kamchatka. Abstracts to Conference "Volcanism and related processes", Petropavlovsk-Kamchatsky, IViS FED RAS, pp. 104-107 (in Russian).

Piip, B.I., 1946. Activity of the Tolbachik volcano (January 1941). Bull. Kamch. Volcanol. Stations 12, 70-73 (in Russian).

Piip, B.I., 1954. Tolbachik volcano. Bull. Kamch. Volcanol. Stations 20, 69-71 (in Russian)

Piip, B.I., 1956. Klyuchevskaya mount and it's eruptions in 1944-1945 and in the past. Bull. Lab. Volcanol. 11, 3-310 (in Russian)

Pineau, F., Semet, M.P., Grassineau, N., Okrugin, V.M., Javoy, M., 1999. The genesis of the stable isotope $(\mathrm{O}, \mathrm{H})$ record in arc magmas: the Kamtchatka's case. Chem. Geol. 153 93-124.

Plank, T., Cooper, L.B., Manning, C.E., 2009. Emerging geothermometers for estimating slab surface temperatures. Nat. Geosci. 2, 611-615.

Ponomareva, V.V., Melekestsev, I.V., Dirksen, O.V., 2006. Sector collapses and large landslides on Late Pleistocene-Holocene volcanoes in Kamchatka, Russia. J. Volcanol. Geotherm. Res. 158, 117-138.

Ponomareva, V.V., Churikova, T.G., Melekestsev, I.V., Braitseva, O.A., Pevzner, M.M., Sulerzhitsky, L.D., 2007a. Late Pleistocene-Holocene volcanism on the Kamchatka peninsula, Northwest Pacific region. In: Eichelberger, J., Izbekov, P., Ruppert, N., Lees, J., Gordeev, E. (Eds.), Volcanism and subduction: the Kamchatka Region. AGU Geophysical Monograph Series vol. 172, pp. 165-198.

Ponomareva, V.V., Kyle, P.R., Pevzner, M.M., Sulerzhitsky, L.D., Hartman, M., 2007b. Holocene eruptive history of Shiveluch volcano. Kamchatka Peninsula. In: Eichelberger, J. Gordeev, E., Kasahara, M., Izbekov, P., Lees, J. (Eds.), Volcanism and Subduction: The Kamchatka Region. American Geophysical Union Geophysical Monograph Series vol. 172, pp. 263-282.

Ponomareva, V., Portnyagin, M., Derkachev, A., Pendea, I.F., Bourgeois, J., Reimer, P.J., Garbe-Schönberg, D., Krasheninnikov, S., Nürnberg, D., 2013. Early Holocene M 6 explosive eruption from Plosky volcanic massif (Kamchatka) and its tephra as link between terrestrial and marine paleoenvironmental records. Int. J. Earth Sci. 102, 1673-1699. http://dx.doi.org/10.1007/s00531-013-0898-0.

Ponomareva, V., Portnyagin, M., Pevzner, M., Blaauw, M., Ph, Kyle, Derkachev, A., 2015. Tephra from andesitic Shiveluch volcano, Kamchatka, NW Pacific: Chronology of explosive eruptions and geochemical fingerprinting of volcanic glass. Int. J. Earth Sci. http://dx.doi.org/10.1007/s00531-015-1156-4.

Ponomaryov, G.P., Puzankov, M.Yu., 2012. Distributions of rock forming elements in system basic-ultrabasic melt between melt and spinel, olivine, orthopyroxene clinopyroxene, plagioclase. Geological application. Moscow, Probel 2000 (664 pp. (in Russian))

Popkov, V.F., 1946. Volcanic activity of Plosky Tolbachik in 1940. Bull. Kamch. Volcanol. Stations 12, 54-63 (in Russian)

Portnyagin, M., Manea, V.C., 2008. Mantle temperature control on composition of arc magmas along the Central Kamchatka Depression. Geology 36 (7), 519-522.

Portnyagin, M., Bindeman, I., Hoernle, K., Hauff, F., 2007a. Geochemistry of primitive lavas of the Central Kamchatka Depression: magma generation at the edge of the Pacific Plate In: Eichelberger, J., Gordeev, E., Izbekov, P., Kasahara, M., Lees, J. (Eds.), Volcanism and subduction: the Kamchatka region. Geophysical Monograph 172, pp. 199-239. 
Portnyagin, M., Hoernle, K., Plechov, P., Mironov, N., Khubunaya, S., 2007b. Constraints on mantle melting and composition and nature of slab components in volcanic arcs from volatiles (H2O, S, Cl, F) and trace elements in melt inclusions from the Kamchatka Arc. Earth Planet. Sci. Lett. 255, 53-69.

Portnyagin, M., Ponomareva, V., Bindeman, I., Hauff, F., Krasheninnikov, S., Kuvikas, O. Mironov, N., Pletchova, A., van den Bogaard, C., Hoernle, K., 2009. Millennial variations of major and trace element and isotope compositions of Klyuchevskoy magmas, Kamchatka. Terra Nostra 1, 64-65.

Powell, M., 1978. Crystallisation conditions of low-pressure cumulate nodules from the Lesser Antilles island arc. Earth Planet. Sci. Lett. 39 (1), 162-172.

Pronin, A.A., Serafimova, E.K., Fedorov, M.V., 1970. The active crater of the Plosky Tolbachik volcano in 1965-1966. Bull. Volcanol. Stations 46, 26-28 (in Russian).

Romanchev, B.P., Flerov, G.B., 1980. The temperatures of lavas of Grate fissure Tolbachik eruption 1975-1976 (Kamchatka). Geochemistry 5, 688-697 (in Russian).

Ruscitto, D.M., Wallace, P.J., Cooper, L.B., Plank, T., 2012. Global variations in H2O/Ce: 2. Relationships to arc magma geochemistry and volatile fluxes. Geochem. Geophys. Geosyst. 13 (3), 1-24, Q03025. http://dx.doi.org/10.1029/2011GC003887.

Saxena, S.K., 1976. Two-pyroxene geothermometer: a model with an approximate solution. Am. Mineral. 61 (7/8), 643-652.

Scholl, D.W., 2007. Viewing the tectonic evolution of the Kamchatka-Aleutian (KAT) connection with an Alaska crustal extrusion perspective. In: Eichelberger, J., Gordeyev, Y., Izbekov, P., Kasahara, M., Lees, J.M. (Eds.), Volcanism and Subduction: the Kamchatka Region. Geophys. Monogr 172, pp. 3-35.

Seliverstov, N.I., 1998. Structure of the near-Kamchatka sea bottom and geodynamics of the Kuril-Kamchatka-Aleutian triple junction. Nauchnij mir, Moscow (164 pp. (in Russian)).

Senyukov, S.L., Droznina, S.Ya., Nuzhdina, I.N., Garbuzova, V.T., Kozhevnikova, T.Yu., 2009. Studies in the activity of Klyuchevskoi volcano by remote sensing techniques between January 1, 2001 and July 31, 2005. J. Volcanol. Seismol. 3 (3), 191-199.

Senyukov, S.L., Nuzhdina, I.N., Droznina, S.Ya., Garbuzova, V.T., Kozhevnikova, T.Yu. Sobolevskaya, O.V., Nazarova, Z.A., Bliznetsov, V.E., 2015. Reprint of "Seismic monitoring of the Plosky Tolbachik eruption in 2012-2013 (Kamchatka Peninsula Russia)". J. Volcanol. Geotherm. Res. 307, 47-59.

Shantser, A.Ye, 1983. Basement xenoliths in the eruption products of the new Tolbachik volcanoes and the problem of formation of magma conduits in the upper crust. In: Fedotov, S.A., Markhinin, Ye.K. (Eds.), The Great Tolbachik Fissure Eruption: Geological and Geophysical Data 1975-1976. Cambridge University Press, Cambridge, pp. 72-82.

Shapiro, N.M., Campillo, M., Stehly, L., Ritzwoller, M.H., 2005. High resolution surface wave tomography from ambient seismic noise. Science 307 (5715), 1615-1618.

Shcherbakov, V.D., Plechov, P.Y., 2010. Petrology of mantle xenoliths in rocks of the Bezymyannyi volcano (Kamchatka). Dokl. Earth Sci. 434 (2), 1317-1320.

Sirin, A.N., 1968. On the relationship between the central and areal volcanism. Nauka, Moscow (196 pp. (in Russian))

Sirin, A.N., Farberov, A.I., 1963. The eruption of Plosky Tolbachik volcano in 1961/62. Bull. Volcanol. Stations 34, 8-11 (in Russian).

Slavina, L.B., Pivovarova, N.B., Senyukov, S.L., 2012. The dynamics of the velocity field beneath the North group of volcanoes, Kamchatka, and its relationship to the evolution of volcanic activity. J. Volcanol. Seismol. 6 (2), 100-115.

Sun, S.S., McDonough, W.F., 1989. Chemical and isotopic systematics of oceanic basalts: implications for mantle composition and processes. In: Saunders, A.D., Norry, M.J. (Eds.), Magmatism in the ocean basins. Geological Society of London, London, pp. 313-345.

Taisne, B., Brenguier, F., Shapiro, N.M., Ferrazzin, V., 2011. Imaging the dynamics of magma propagation using radiated seismic intensity. Geophys. Res. Lett. 38 L04304. http://dx.doi.org/10.1029/2010GL046068.

Taylor, H.P., 1980. The effects of assimilation of country rocks by magmas ${ }^{18} \mathrm{O} /{ }^{16} \mathrm{O}$ and ${ }^{87} \mathrm{Sr} /{ }^{86} \mathrm{Sr}$ systematic in igneous rocks. Earth Planet. Sci. Lett. 47, 243-254.

Telling, J., Flower, V.J.B., Carn, S.A., 2015. A multi-sensor satellite assessment of $\mathrm{SO}_{2}$ emissions from the 2012-13 eruption of Plosky Tolbachik volcano, Kamchatka. J. Volcanol. Geotherm. Res. 307, 98-106.

Thelen, W., West, M., Senyukov, S., 2010. Seismic characterization of the fall 2007 eruptive sequence at Bezymianny volcano, Russia. J. Volcanol. Geotherm. Res. 194, 201-213.

Thompson, R.N., 1975. The 1-atmosphere liquidus oxygen fugacities of some tholeiitic intermediate, alkalic and ultra-alkalic lavas. Am. J. Sci. 275, 1049-1072.
Timerbaeva, K.M., 1967. Petrology of Klyuchevskoy volcanoes in Kamchatka. Nauka, Moscow (209 pp. (in Russian)).

Tokarev, P.I., 1978. Prediction and characteristics of the 1975 eruption of Tolbachik volcano, Kamchatka. Bull. Volcanol. 41, 251-258

Tokarev, P.I., Zobin, V.M., 1970. The peculiarity of the propagation of the seismic waves of the close earthquakes in the Earth's crust and upper mantle in the area of Klyuchevskaya group of volcanoes at Kamchatka. Bull. Volcanol. Stations 4, 17-23 (in Russian).

Turner, S., McDermott, F., Hawkesworth, C., Kepezhinskas, P., 1998. A U-series study of lavas from Kamchatka and the Aleutians: constraints on source composition and melting processes. Contrib. Mineral. Petrol. 133, 217-234.

Turner, S., Evans, P., Hawkesworth, C., 2001. Ultrafast source-to-surface movement of melt at island 574 arcs from ${ }^{226} \mathrm{Ra}^{230}{ }^{23} \mathrm{Th}$ systematics. Science $292,1363-1366$.

Turner, S., Sims, K.W.W., Reagan, M., Cook, C., 2007. A ${ }^{210} \mathrm{~Pb}^{226} \mathrm{Ra}^{230}{ }^{23} \mathrm{Th}^{238} \mathrm{U}$ study of Klyuchevskoy and Bezymianny volcanoes, Kamchatka. Geochim. Cosmochim. Acta 71, 4771-4785.

Turner, S., Izbekov, P., Langmuir, C., 2013. The magma plumbing system of Bezymianny volcano: insights from a 54 year time series of trace element whole-rock geochemistry and amphibole compositions. J. Volcanol. Geotherm. Res. 263, 108-121.

Uspensky, V.S., Shapiro, M.N., 1984. Late-Quaternary areal volcanism of the Kumroch Range (Eastern Kamchatka). Volcanol. Seismol. 1, 57-66 (in Russian).

van Keken, P.E., Hacker, B.R., Syracuse, E.M., Abers, G.A., 2011. Subduction factory: 4. Depth-dependent flux of $\mathrm{H}_{2} \mathrm{O}$ from subducting slabs worldwide. J. Geophys. Res. 116, B01401. http://dx.doi.org/10.1029/2010JB007922.

Vergasova, L.P., Filatov, S.K., 2012. New mineral species in products of fumarole activity of the Great Tolbachik Fissure Eruption. J. Volcanol. Seismol. 6 (5), 281-289.

Vergasova, L.P., Filatov, S.K., Dunin-Barkovskaya, V.V., 2007. Posteruptive activity on the first cone of the Great Tolbachik Fissure Eruption and recent volcanogenic generation of bauxites. J. Volcanol. Seismol. 1 (2), 119-139.

Vlodavets, V.I., 1937. Visit the crater of the volcano Plosky Tolbachik on August 13, 1936. Bull. Kamch. Volcanol. Stations 2, 27-34 (in Russian).

Vlodavets, V.I., 1940. Klyuchavskaya volcanic group. Bull. Kamch. Volcanol. Stations 1 (124 pp. (in Russian))

Vlodavets, V.I., Piip, B.I., 1957. Catalogue of active volcanoes of Kamchatka. Bull. Volcanol. Stations 25, 5-95 (in Russian).

Volynets, ON 1994. Geochemical types, petrology and genesis of Late Cenozoic volcanic rocks from the Kurile-Kamchatka island-arc system. Int. Geol. Rev. 36 (4), 373-405.

Volynets, O.N., Ponomareva, V.V., Babansky, A.D., 1997. Magnesian basalts of Shiveluch andesite volcano, Kamchatka. Petrology 5 (2), 183-196.

Volynets, O.N., Babanskii, A.D., Goltsman, Y.V., 2000. Variations in isotopic and traceelement composition of lavas from volcanoes of the northern group, Kamchatka, in relation to specific features of subduction. Geochem. Int. 38 (10), 974-989.

Volynets, A.O., Churikova, T., Wörner, G., Gordeychik, B., Layer, P., 2010. Mafic Late Miocene-Quaternary volcanic rocks in the Kamchatka back arc region: implications for subduction geometry and slab history at the Pacific-Aleutian junction. Contrib. Mineral. Petrol. 159, 659-687. http://dx.doi.org/10.1007/s00410-009-0447-9.

Volynets, A.O., Melnikov, D.V., Yakushev, A.I., 2013. First data on composition of the volcanic rocks of the IVS 50th anniversary fissure Tolbachik eruption (Kamchatka). Dokl. Earth Sci. 452 (1), 953-957. http://dx.doi.org/10.1134/S1028334X13090201.

Volynets, A.O., Edwards, B.R., Melnikov, D, Yakushev, A, Griboedova, I, 2015. Monitoring of the volcanic rock compositions during the 2012-2013 fissure eruption at Tolbachik volcano, Kamchatka. J. Volcanol. Geotherm. Res. 307, 120-132.

Wells, P.R.A., 1977. Pyroxene thermometry in simple and complex systems. Contrib. Mineral. Petrol. 62 (2), 129-139.

West, M.E., 2013. Recent eruptions at Bezymianny volcano - a seismological comparison. J. Volcanol. Geotherm. Res. 263, 42-57. http://dx.doi.org/10.1016/j.jvolgeores.2012. 12.015

Yogodzinski, G.M., Lees, J.M., Churikova, T.G., Dorendorf, F., Woerner, G., Volynets, O.N., 2001. Geochemical evidence for the melting of subducting oceanic lithosphere at plate edges. Nature 409, 500-504.

Zavaritsky, A.N., Piip, B.I., Gorshkov, G.S., 1954. The studies of the Kamchatka volcanoes. Trudy of laboratory of Volcanology, Moscow 8 pp. 18-57. 